\title{
Systematic and Grounded Theory Literature Reviews of Software Process Improvement Phenomena: Implications for IS Research
}

\author{
Samuel C. Avemaria Utulu \\ Department of Information Systems, \\ University of Cape Town, South Africa; \\ Redeemer's Library, Redeemer's University, Nigeria
}

utlsam001@myuct.ac.za

Kosheek Sewchurran

Graduate School of Business, University of Cape Town, South Africa

Kosheek.sewchurran@gsb.uct.ac.za

\section{Barry Dwolatzky \\ School of Electrical and Information Engineering, University of the Witwatersrand, Johannesburg, South Africa}

Barry.Dwolatzky@wit.ac.za

\begin{abstract}
Material published as part of this publication, either on-line or in print, is copyrighted by the Informing Science Institute. Permission to make digital or paper copy of part or all of these works for personal or classroom use is granted without fee provided that the copies are not made or distributed for profit or commercial advantage AND that copies 1) bear this notice in full and 2) give the full citation on the first page. It is permissible to abstract these works so long as credit is given. To copy in all other cases or to republish or to post on a server or to redistribute to lists requires specific permission and payment of a fee. Contact Publisher@InformingScience.org to request redistribution permission.
\end{abstract}

Over the years, there seems to be little achievement made with regards to effective measurement of software development organizations' capabilities, especially with regards to their effective implementation of Software Process Improvement (SPI) programs. This problem has been ascribed to the limitations which the capability models have in terms of accurately identifying organizational variables which will appropriately serve as capability measures. This study, therefore, argues that variables such as knowledge economy, corporate ideology, organizational design, quality management, and performance management can evolve in IS research as primary measures required to accurately measure software development organizations' capabilities. The methods that were adopted are the grounded theory literature review and the systematic literature review methods. The grounded theory literature review allowed the authors to carry out a rigorous review of the literature on subjects, namely, knowledge economy, organizational sciences, quality

management, and performance management, with the aim of pointing out the need for a conceptual shift in SPI research. The systematic literature review was used to descriptively analyze 14 IS based articles published in five hand-picked IS research publication outlets. We found out that there is need for IS based SPI researchers to study knowledge economy, corporate ideology, organizational design, quality man- 
agement and performance management as intertwined variables and not as separate variables as currently being practiced in the field. We also found out that IS based SPI research is multidisciplinary in nature and are mainly carried out as literature reviews and action research. We recommend that IS researchers should endeavour to bring together these variables since they influence one anther in order to be able to carry out more formidable analysis of the issues affecting the measurement of software development organizations' capability and how it affect the implementation of SPI programs. This research contributed theoretically to the IS SPI literature.

Keywords: software process improvement, knowledge society, organizational design, quality management, performance, systematic literature review, grounded theory literature review

Acknowledgement: the authors acknowledge funding received in support of some aspects of this work from the Employment Creation Fund (ECF) through the Department of Trade and Industry, South Africa.

\section{Introduction}

Software process improvement (SPI) has been in the literature for quite sometime now. It has generated all sorts of arguments from different academic perspectives, especially with regard to how it should be implemented to achieve its intent of improving on the performances of software engineers that are practically involved with software production. It has also generated argument with regards to the capability of software organizations that provide work contexts for software engineers. Consequently, Unterkalmsteiner et al. (2012) opined that SPI addresses activities that are aimed at improving the software development process through the assessment and improvement of the processes and practices involved in software development. It therefore, follows that SPI objectives pose a great deal of challenge on those implementing it who had to decide if it is an organizational change program or just a process and practice management programs (Pourkomeylian, 2006). However, the evolution of normative models such as the Capability Maturity Model (CMM), SPICE, and CMMI has evolved a thinking pattern among SPI practitioners that makes them initiate SPI as an organizational wide program. As a result, researchers have tried to use elements of organizational and behavioral sciences to evaluate factors that impact SPI, how these factors develop into SPI risks and how they can be managed (Aaen, 2002; Debou \& Kuntzmann-Combelles, 2000; Iversen, Mathiassen, \& Nielsen, 2004; Ngwenyama \& Nielsen, 2003; Ngwenyama \& Norbjerb, 2010).

Despite the increasing amount of research that has been dedicated to studying SPI phenomena as an organization wide phenomena, very few considered how organizational design factors may form causal variables that have diverse impact on SPI programs, while as far as we know, none tried to assess the causal relationship that may exist between knowledge economy, corporate ideology, organizational design, quality management and performance management, and SPI outcomes. This is despite the fact that the literature emanating in the recent past has developed claims that the knowledge economy has impacted contemporary corporate ideology, organizational design, quality management, and performance management. We derive this position from Whitty and Schultz (2007) who suggest that the cultural structure enshrined in a society or organization results from the ideologies that have become part of a society's value system. This situation is rather pathetic because SPI is based on the tenets of ensuring acceptable business philosophies, organizational fits, quality products and acceptable level of corporate performance (Paulk, Weber, Curtis, \& Chrissis, 1994). Invariably, we are aware that despite the fact that most software development organizations are small and medium sized, that they exist and operate in the current knowledge economy, have corporate ideologies, and are structured into different levels of management where their corporate ideologies are actualized in different organizational contexts (Bernroider, 2002). This provided the clue to the fact that corporate ideology actualization reflects on the kind of organizational design, quality management, and performance management 
that software development organizations adopt in the contemporary knowledge economy. This obvious clue led to our adoption of grounded theory literature review method as a way of developing appropriate theory for our claim, on the one hand, and projecting for a conceptual shift on the other hand.

However, there are numerous studies in the literature attesting to our claim. For example, Halloran (2004) echoed the need to address SPI from the point of view of a program that is meant to evaluate processes in socio-cultural systems that comprise the larger environment and organizational elements, attributes and behaviours. Halloran specifically noted the pressing need for assessing organizational learning and knowledge management as variables that influences SPI programs outcomes. In another instance, Pourkomeylian (2006) put forward that SPI approaches are dictated by three ideas: evolutionary nature of SPI, idealized normative models of software engineering, and conscious creation and development of commitment between actors involved. The idea is that Holloran's and Pourkomeylian's claims show that SPI programs are organizational programs that may be impacted by the nature of the organization where it is being implemented. However, their assertions have limitations that resulted because of their presumed assumption that organizational learning, knowledge management, and management commitment can be achieved automatically without recourse to the influence of the knowledge economy and how it impacts corporate ideology formation and organizational design. Despite this, they, together with other authors who did similar studies, have helped to provide a foundation on the need to look at corporate ideology and organizational design as factors that may influence variables such as knowledge management, quality management, performance and management that have earlier been linked with SPI programs failures and successes.

Consequently, this paper reports research carried out using the grounded theory literature review method with the aim of bringing together theories concerning knowledge economy, corporate ideology, organizational design, quality management, and performance management in order to proffer a conceptual shift in the ways software development organizations' capability and SPI phenomena are researched. It also reported the results of the systematic literature review (SLR) carried out on selected IS based SPI research publications in the IS literature. The primary aim of using the SLR on IS literature was to find out if IS researchers study these variables individually or as causal or influential variables why studying software development organizations capability and SPI phenomena. We assume that the outcome of this research would provide the foundation upon which we can build arguments regarding the ways software development organizations' capability and SPI phenomena can be studied from a thinking involving the identified variables. We also made recommendations based on the reason why IS researchers should, unlike researchers from other fields, bring together knowledge economy, corporate ideology, organizational design, quality management, and performance management as combine causal variables when studying software development organizations capability and SPI phenomena. It is hoped that the assessment will allow the authors to develop a list of areas of further research.

As a result, the central questions asked in the study are (1) Do knowledge economy, corporate ideology, organizational design, quality management, and performance management have any impact on the extent to which researchers and practitioners are able to accurately and appropriately measure software development organizations' capabilities and SPI phenomena? (2) How has IS research contributed to the meaningful understanding of factors impacting SPI from the perspectives of knowledge economy, corporate ideology, organizational design, quality management, and performance management? We used grounded theory literature review as strategy to answer question one and SLR as strategy to answer question two. The paper therefore, assesses the core features of existing approaches to software development organizations capability and SPI research and identifies need for a conceptual shift that responds more closely to the dynamic nature of contemporary organizations from IS perspective. The remaining segments of this paper 
are as follows: conceptual development of SPI phenomenon, definition of SPI, grounded theory literature review, discussion of themes from grounded theory literature review, systematic literature review methodology, scope and themes, search strategy and selection, data extraction, IS research and socio-technical phenomena in software development organizations, recommendations for future research and conclusion.

\section{Conceptual Development of SPI Phenomenon}

Various reasons have been given in the SPI literature as factors that influence the emergence of SPI as a concept and practice. For instance, Moitra (1998) opined that the importance of software in the contemporary global economy, which resulted in the need for high quality software, gave birth to improvement programs in software development organizations. Moitra maintains that the need to achieve product quality objectives of software development organizations resulted in the development of methods for evaluating, improving and reporting re-usable quality actions by software development organizations during any software development project. These structured actions were later to be known as SPI. Naizi, Wilson, and Zowghi's (2005) opinion on the evolution of SPI is similar to that reported in Moitra (1998). According to Naizi and his colleagues the important role software plays in modern-day business (knowledge base economic activities) and life style (socio-cultural), and the increase in the rate at which large software projects fail (product quality and organizational performance) necessitated the evolution of SPI research and practices in both academia and industry.

For Dyba (2000), the conceptual development of SPI can be traced to the need to eliminate increasing software failures experienced by customers. As a result, Dyba's arguments with regard to SPI were developed from the perspective of analyzing key success factors for SPI programs. Ngwenyama and Nielsen (2003) discussed the development of SPI from the point of view of the need to reinforce quality and productivity improvement programs in software development organizations. This is to say that the introduction of SPI programs is not necessarily done when quality and productivity are threatened, but can also be done when current quality and productivity need to be evaluated and increased. In another study, Iversen and Ngwenyama (2006) observed a shift from the reasons why SPI programs were mounted by software development organizations. According to the duo, SPI related needs, such as the need to ensure quality, productivity, and to meet new software requirements that are evolving due to changing social needs, led to continuous and unrelenting global competition in the software industry. This is on the one hand. On the other hand, Iversen and Ngwenyama noted that the increase in software engineering skills and proficiency in Asia which threatened software production and marketing in Europe and North America also resulted into the global competition that led to the intensification of SPI programs.

Staples and Niazi (2008) conducted a systematic review of organizational motivations for adopting CMM-based SPI and in the end found out that the reasons for carrying out SPI projects are "usually related to product quality and project performance, and less commonly, to process (p. 605)." According to Hannola, Oinonen, and Nukula (2011), SPI aims include "to improve the effectiveness of the software development process by assessing and understanding the existing processes, changing these processes to reduce the costs and development time of software produced and to improve software quality" (p. 42). Ngwenyama and Norbjerg (2010) brought in the idea of the evolution of SPI as a result of the need to manage organizational change that improves the performance of software organizations. They noted that increase in organization performance as a result of organizational change allows software organizations to improve on the predictability, quality, and productivity of their software processes. It suffices to say that SPI evolved as an organizational strategy that is meant to propel changes that had to do with socio-cultural, economic, performance, competitiveness, and organizational change aspects of software development organizations. Consequently, variables such as knowledge economy, corporate ideology, 
organizational design and quality and performance management are fundamental to planning, implementing, and assessing both software development organizations and their SPI programs. We strongly assume that to achieve the SPI objectives (effective operations in contemporary business environment, dynamic and responsive organization, production of quality products and achievement of set organizational performance standards) these variables need to be assessed together and not separately.

\section{Definition of SPI}

Although definitions of SPI can be easily coined from the conceptual evolution reviewed in the segment above, we consider it appropriate to assess the ways SPI researchers attempted to develop a working definition for SPI as a concept and practice. Aaen (2002) for instance, defined SPI as being "about changing software organizations populated by technical and highly specialized people working with complex tasks, using a variety of methods and tools" (p. 380). Aaen further describes SPI as comprising of activities that lead to the design of the architecture of software process which helps in establishing and realizing a future vision and developing tools to support the software process. According to Mathiassen, Ngwenyama, and Aaen (2005 p. 84) SPI can be defined as activities that spell out "primary approach to improving software quality and reliability, employee and customer satisfaction, and return on investment." Unterkalmsteiner et al. (2012) surmise that SPI initiatives refer to activities aimed at improving software development processes in which software process measurement, which allows predictable performance, high capability, and the achievement of quality requirements, are a core part. These definitions see SPI as involving organizational phenomena, approaches, changes, and initiatives.

Gorschek and Davis (2008) put forward that SPI deals with various independent variables required for process change in software development. Process change in software development organizations comprises changes meant to impact on software requirement phase, software project management practices, software product and service quality assurance, redesign of software organizations and delivery of quality software product and services to society. This can make us deduce that SPI is a management activity that spans through the operational, managerial/tactical, and strategic/executive levels of management to external influences such as software development organizations owners objectives and ideology, stakeholders and customers needs, and current socio-economic environment. This is because the independent variables identified by Gorschek and Davis (2008) comprise both internal (requirement phase, project, and product), which can be managed at both operational and managerial levels, and external (benefits to society), which may be managed at the executive and strategic levels. However, we have observed that most SPI research reported in the literature assessed SPI functions at the operational level leaving out (not totally in most cases) the impact which the managerial/tactical and strategic/executive levels can have on the overall plan, resource allocation, management support, and practical application of the knowledge gained from SPI initiatives. The implication of this is that the scopes of these studies did not fully cover every aspect inherent in the implementation of SPI programs as shown through SPI definitions reviewed in the earlier part of this paper. Consequently, Figure 1 illustrates how different management levels can impact, and be impacted by, SPI programs. 


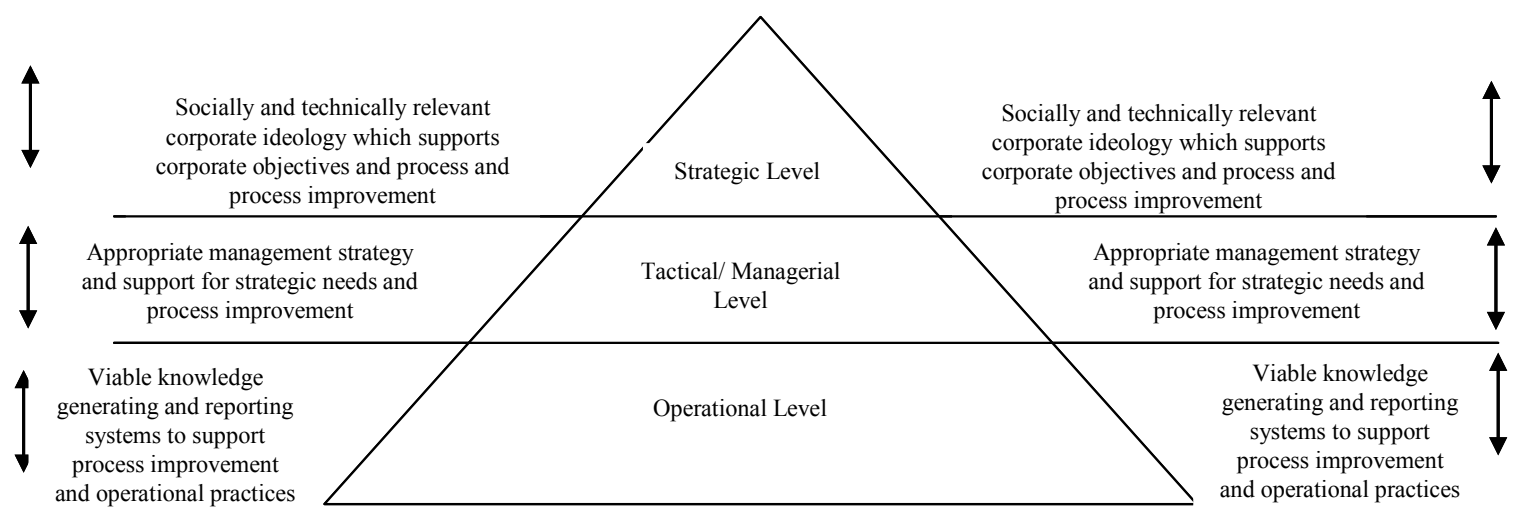

Figure 1: Dynamics of SPI Program across Management Levels

\section{Grounded Theory Literature Review of Knowledge Economy, Organizational Design, Quality and Performance Management as Factors in SPI Research}

Wolfwinkel, Furtmueller, E., \& Wilderom (2013) reported how grounded theory approach advanced by Strauss and Corbin $(1990,1998)$ can be used as a method for rigorously reviewing literature. They surmised that "applying grounded theory aims to point to well-rooted and fruitful new links between variables" (p. 2). The need for fruitful new links between variables necessitated our choice of the grounded theory literature review method, since our objective was to find out new variables that impact on software development organizations capability and SPI outcomes. We considered four key issues, namely, sampling, creativity, reflexivity, and precision, pointed out by Cutcliffe (2000) as fundamental to the use of grounded theory as a research method. We viewed software development organizations as organizations with social systems that are open and influenced by both external and internal factors based on the proposition of Blumberg (1987). We developed our sampling from variables already used in the literature that addresses SPI as an organizational issue such as knowledge management, organizational learning, organizational culture, and management support. We set our reflex on these variables and then created larger variables namely, knowledge economy, corporate ideology, organizational design, quality management, and performance management from which we can have a deeper and more holistic perspective of software development organizations as the sample concepts for the grounded theory literature review method. We created knowledge economy as a major set of sample because of its obvious effect on how business and management ideologies are formed and implemented in the recent past. Figure 2 shows the representation of the sets of literature that we selected as samples and how we conceptualized them as combined variables. We conceptualize that knowledge economy impact corporate ideology, organizational design, quality management and performance management are all operationalized by software development organizations in the knowledge economy. 


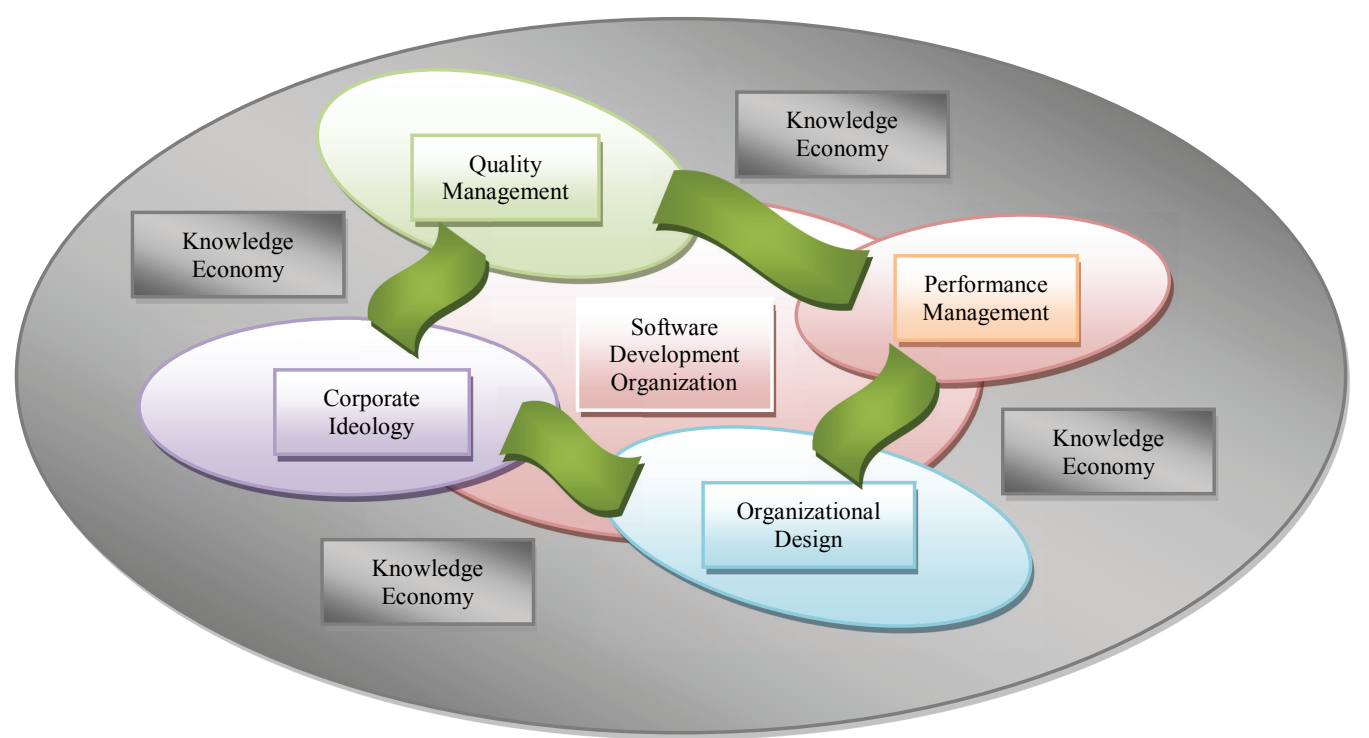

Figure 2: Representation of the Sampled Literature Using Grounded Theory Literature Review Method

Wolfwinkel and his colleagues (2013) agreed that grounded theory literature review may have been used in tacit ways by Alavi and Leidner (2001) and Glynn and Raffaelli (2010) and therefore means that authors may as well be familiar with using literature review to establish new links between variables. However, to formalize the grounded theory literature review method the fivestage process which Wilfwinkel et al. (2011) proposed was adopted. Our intention was to adopt all five stages for our study as a way of formalizing the use of grounded theory literature review method. The five stages are:

1. DEFINE

i. Define the criteria for inclusion/exclusion

ii. Identify the fields of research

iii. Determine the appropriate sources

iv. Decide on the specific search terms

2. SEARCH

i. Search

3. SELECT

i. Refine sample

4. ANALYZE

i. Open coding

ii. Axial coding

iii. Selective coding

5. PRESENT

i. Represent and structure the content

ii. Structure the article

We defined our criteria by agreeing that external factors such as knowledge economy and corporate ideology may have impact on organizational design, organizational culture, organization context, work systems, quality management, and performance management which primarily influ- 
ence how software development organizations attain capabilities that determine how they manage SPI programs. We then identified that, despite the fact that these topics are multidisciplinary, they are mostly studied by fields in the management sciences. Since management science is a vast field, we agreed that the best source of literature that will cover the internal and external variables identified in the study would be Google scholar. Google scholar has the advantage of returning a higher retrieval rate than database sources such as Scopus, science direct, Emerald and other specific databases. We then decided that the variables' keywords (used as search terms) would be used as search terms. For example, knowledge economy was used as search term for searching for and retrieving scholarly works that dealt with the subject 'knowledge economy.' We are aware that the variables treated in these paper have synonyms, for instance, knowledge economy may be tagged 'knowledge society'. Quality management may also be tagged 'total quality management' even though they are different conceptually. The advantage of using Google scholar is that it returned terms with both the search terms we adopted and the synonyms which may have been used for them by both their authors as keywords and Google scholar search engines indexing systems as index terms. However, we selected the literature we used spontaneously without recourse to any framework since Google scholar returned a high rate of scholarly works.

We carried out each search once and also used references available in each retrieved documents references to expand our reach to the documents we used for the study. Our analysis was based on subject analysis, that is, reading through the concepts and arguments of each document retrieved first in the abstract for final selection and then reading through the document. So our approach to the grounded theory literature review we used as shown in Figure 3:

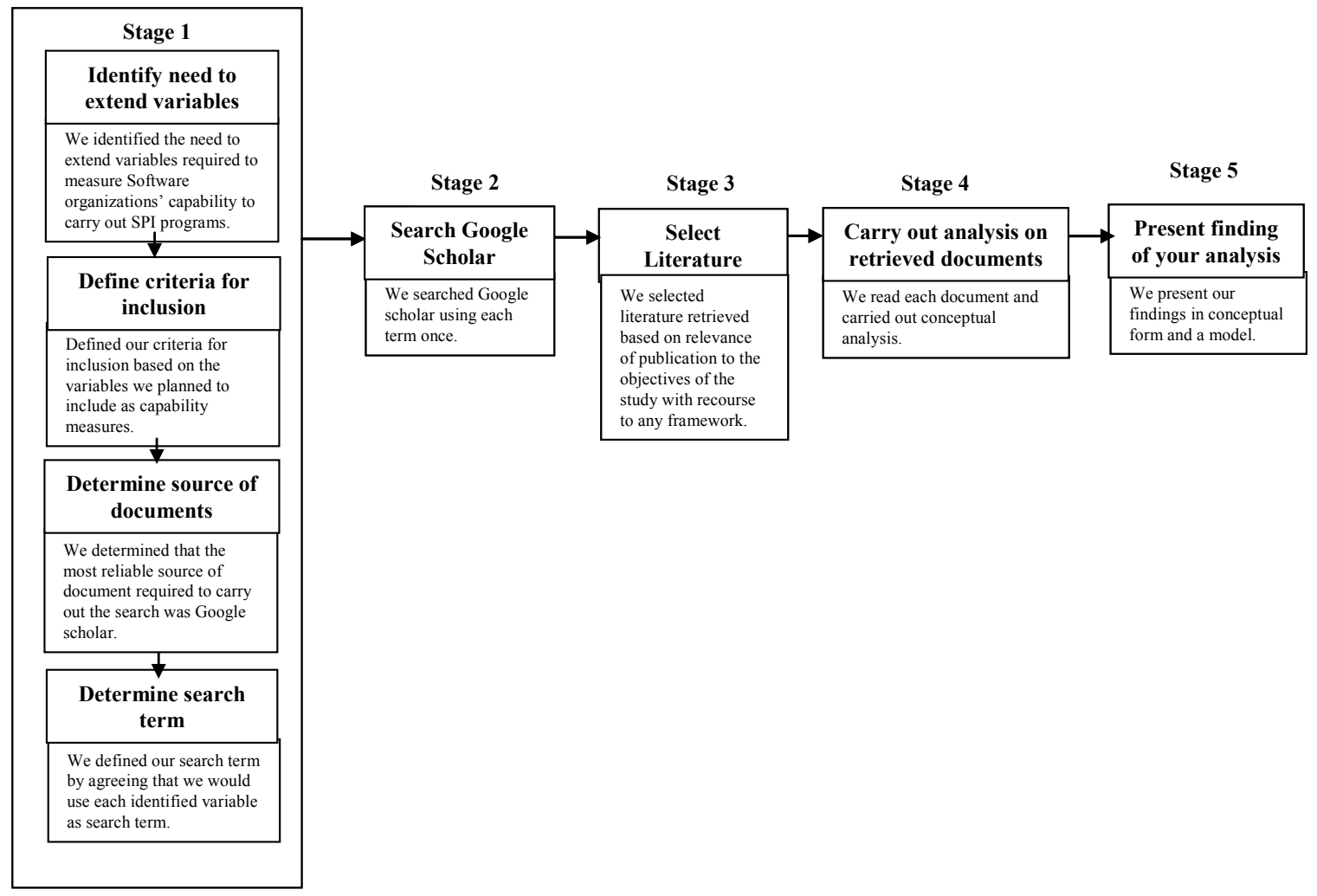

Figure 3: Five Stages of Grounded Theory Literature Review Method 


\section{Grounded Theory Literature Review Results}

We find out that since Peter Drucker (1969) observed the transformation of the global economy from industrial to knowledge based economy in the 1950s, all socio-cultural, political, and economic activities surrounding human existence have continued to be knowledge dependent. The knowledge revolution that started during this period has solidified over the years and has resulted in making some societies knowledge societies. These societies are referred to as knowledge societies because they derive their socio-cultural, political, and economic advantages from judicious creation, management, and use of information as raw material for creating knowledge and for driving innovation (and Britz, Lor, Coetzee, \& Bester, 2006; Kisielnicki \& Sobolewska, 2010). One major factor that gives business organizations in knowledge societies critical edge in the global knowledge economy is their ability to invent and manipulate social structures that are driven by information and communication technologies to generate and turn information into knowledge (James, 2003). These organizations tend to make good use of the knowledge they gained through careful assessment of social interactions within and outside them when implementing their corporate objectives. The knowledge economy has consequently evolved a situation in which business organizations in the recent past adopt corporate ideologies that facilitate organizational knowledge generation and use (Kaplan \& Norton, 2000; Zmud, Boynton, \& Jacobs, 1986). In other words, the prevailing ideology among business organizations in the recent past is the knowledge creation and use ideology. We observe that corporate ideology means the beliefs and values enforced into an organization by its owners through top level managers and those developed by personnel within the organization based on their experiences and social interactions especially as influenced by the prevailing corporate ideology (Goll and Zeitz, 1991).

We observe that while much did not change about the philosophical assumptions of the management approaches (classical, behavioural, and system approach) that contemporary business organizations adopt, what changes is their use of corporate ideologies to impact their organizational designs, and quality and performance management. In contemporary time, organizational design allows business organizations to tighten or loosen the flow of corporate knowledge and to engage in knowledge management activities that allow them gain access to the knowledge they need to implement and assess their business processes, product quality and organizational performance. A good example of this scenario is shown in Martin's (2010) description of the evolution of customer capitalism which evolved when managerial capitalism was considered to be out of fashion. Martin made allusion to the role knowledge generation and use played in scenarios where either of the two types of capitalism was practiced. The central theme of Martin's argument was that professional management which characterizes managerial capitalism came on board in the early 1930s because professional managers were believed to have been trained and equipped with the knowledge required to run business organizations, on the one hand. On the other hand, customer capitalism emerged when it was realized that the knowledge a business organization needs to achieve its corporate objectives was that that gives it accurate and adequate information about its customers' value proposition and how to satisfy its stakeholders.

Consequently, the shift in corporate ideology conceptualization ushered in the managerial capitalism epoch that favoured the design of organizations in manners that gave precedence to practices that allowed managers access to all sought of knowledge resources that they need to do their jobs as coordinators, resource allocators, and personnel motivators. This epoch was characterized by the deployment of management information systems and knowledge management systems by corporate organizations (Alavi \& Leidner, 2001; Livari \& Huisman, 2007; Tanriverdi, 2005). During the customer capitalism era, which has gradually transformed into stakeholders capitalism era, corporate ideologies were tilted in favour of organizational designs that support the creation and use of knowledge not only on customers wants and needs, but on every identified stakeholders' wants and needs (Perrini \& Tencati, 2006). This allows managers to coordinate, allocate re- 
sources and motivate personnel toward the broad goal of knowing stakeholders' wants and needs, and how these needs and wants can be effectively and efficiently met (Neely, Adams, \& Crowe, 2001; Zmud et al., 1986). The body of literature, some of which are listed below, available on enterprise resource planning (Evgeniou, 2002; Gattiker and Groodhue, 2004; Hitt, Wu, \& Shou, 2002), extended enterprise resource planning (Alfaro, Rodriguez-Rodriguez, Verdecho, \& Ortiz, 2009), supply chain management (Carter \& Roger, 2008; Cho, Ozment, \& Sink, 2008; Premkumar, 2000), quality management (Rust, Moorman, \& Dickson, 2002; Shredinck, Shutt, \& Weiss, 1992; Sousa \& Voss, 2002), performance management (Barclay, 1993; Burke \& Litwin, 1992; Garengo, Nudurupati, \& Bititci, 2007; Palaniswamy \& Frank, 2000), work (Checkland, 1981; Oakland \& Oakland, 2001; Way, 2002) and knowledge management (Alavi \& Leidner, 2001; Turner \& Makhija, 2006; Widden-Wulff \& Ginman, 2004) has done justice on the conceptualization, theory development and empirical evaluation of conceptual changes in the ways corporate ideologies were conceptualized to shift the ways contemporary organizations meet their competitive.

Goll and Zeitz's (1991) position that corporate ideology is "consisting of the beliefs and values about the world that provide the frame of reference for organizational action" (p. 192) and therefore "affects...behaviour at all levels of the organization" (p. 193) can be used to set the tone for the impact of corporate ideology on organizational culture and management strategies. Contemporary organizations now have corporate ideologies that influence the shaping of their structures in a manner that reinforces the generation, organization, use and preservation of knowledge resources (Huber, 1991). This argument can be corroborated by Johnson, Christensen, and Kagermann's (2008) proposition on how contemporary organizations could reinvent their business model. Johnson and his colleagues proposed a business model with four elements, namely, customers value proposition, profit formula, key resources, and key processes. The model succinctly points to the need for contemporary organizations to have adequate knowledge of their customers, profit strategies, resources, and processes. It, therefore, follows that the model encourages organizations to develop corporate ideologies that supports the design of organizations in such a manner that will help them generate and use organizational knowledge as primary reference, not only for decisions concerning their customers, profit strategies and resource allocation, but also on their business processes. The impact of organizational culture, an element of management ideology, on organizational behaviour and communication was highlighted by Bates, Amundson, Schroeder, and Morris (1995) and Koufteros, Nahm, Cheng, and Lai (2007) in their studies where they described how management ideology breeds organizational design, structure, culture, behaviour, and communication.

While trying to explain the importance of corporate ideology Goll and Zeitz (1991) posited that "ideology clearly resembles and partially overlaps with culture...strategic plan and goals, since all three contain belief and value assumptions and are meant to guide action" (p. 191). Earlier, studies on corporate ideology have revealed that it provides legitimization both to internal and external stakeholders (Pfeffer, 1981), shape strategic choices (Hambrik \& Mason, 1984), and impact on organizational practices (Beyer, 1981). It has been reported in the literature that corporate ideologies develop in organizations as a result of their owners, sizes, number of employees, and sizes of projects that they handled over time (Kelly \& Culleton, 1999). Sturdivant, Ginter, and Sawyer (1985) helped us to understand the role owners and managers play in shaping organizational ideology by stating that the beliefs and values that are more favoured by a dominant class within an organization determine its ideological beliefs and values and how it is conceptualized and assessed. However, James (2003) put forward that in contemporary time corporate ideologies are shaped to ensure the evolution of learning organization, that is, a type of organization that values and beliefs that corporate learning ensures corporate advantages over competitors' strategies. 
Owing to the claims above, studies that have looked into organizational culture in software development organizations, especially with regards to SPI, can be adjudged as having significant limitations because of their non-consideration of corporate ideology as a factor that may breed cultural influence on SPI practices especially as dictated by the evolution of the knowledge economy. A good example is Aaen (2002) who identified the role of SPI as infrastructure and culture building. His argument relied only on concepts available in knowledge management and organizational design literature without making reference to corporate ideology, a factor that breeds organizational design and culture. Close to this piece-meal style is Dyba (2000) who used quality management and organizational learning to identify key success factors in SPI programs. In order to be thorough, Dyba's argument should have put into consideration factors such as corporate ideology and organizational design which breed quality management and organizational learning. James (2003) was of this opinion when she argued that successful business organizations that hope to implement a learning organization may not succeed by "focusing on a few components or on process alone" (p. 46). Ngwenyama and Nielsen's (2003) findings of contradictory set of assumptions about organizational culture in the CMM approach to SPI may have resulted as a consequence of the way CMM handled factors that breed organizational culture.

Major challenges software development organizations face with regards to their SPI programs emanate because of their organizational design which the literature has shown to be a function of corporate ideology. For instance, Kelly and Culleton (1999) opined that "there is always the danger of introducing a CMM-compliant process that does not fit your organization or that involves too much over head" (p. 43). The structural contingency theory, a classical theory of organizational design, posits that organizational design that must bring about positive change should take into cognizance five variables, namely, environmental dynamism and uncertainty, strategies, technology, type of dependence, and systems size. The theory has been used by scholars to interpret how contextual variables have been connected through the notion of fits-selection fit, interactional fit and systemic fits- to organizational design (Drazin \& Van de Ven, 1985; Grandori \& Furnari, 2007; Mintzberg, 1979). We interpret strategies, one of the variables listed in the structural contingency theory, to include corporate ideology as indicated by Goll and Zeitz (1991) and concur that all the five variables can play major roles in determining the level of success software development organization can attain when implementing SPI programs.

In practice, during organizational design exercises attention is normally paid to how organizations would be able to support or hamper or control the free flow of knowledge both within and outside it. Visscher and Visscher-Voerman (2010) did a study in which they described three (pragmatic, dialogical, and rational) approaches to organization design adopted by a group of consultants. They explained that each approach is motivated by the need to objectively design an organization that will meet all stakeholders' needs, or by the need to provide an avenue for those dominating the political power in an organization to maintain their power, or by the need to systematically understand, analyze and solve problems that may have resulted due to prevailing organization design. Consequently, Moreno-Luson and Peris (1998) provided the following as organization design variables: level of decision-making centralization, level of formalization-standardization, and the level of common shared values in the firm. Grandori and Furnari (2008) called for a more careful analysis and the selection of basic organizational elements during organization design and analysis. This according to the duo will allow for a clearer identification and understanding of basic organizational elements that may be configured or complemented using the configured and complementarity-based approaches to achieve the fits (selection fit, interaction fit, and systemic fit) that are necessary for high performing organizations. Grandori and Furnari revealed that organizational design that put into cognizance organizational configuration and attribute complementarity-based approaches lead to a design that addresses social issues. This allows the improvement of attractiveness and creativity in intra-organizational relationships, and the extent to which an organization can employ hierarchy, teamwork, programs, and specialization, 
among others. James (2003) surmised that six macro properties, namely, transformational leadership, dispersed strategies, horizontal structures, integrating mechanisms, egalitarian cultures, and knowledge workers, are necessary components of an organization that is open, exploitative and explorative, and able to learn.

Earlier, studies by Galbraith (1974) and Tushman and Nadler (1986) have explained how the need for information processing determines both internal and external organizational design needs. Such needs as to how to integrate tasks among sub-units to reduce uncertainty and how to ensure that tasks are not integrated into different sub-units when it is possible for them to be handled by a sub-unit are required to be taken seriously when designing organizations. Scholars in favour of the information processing based organization design practices are of the opinion that organizational fits are required primarily because of the need to support intra-organizational information processing. One thing common to the literature referenced above, irrespective of their approaches is that organizational design has to do with careful integration of organizational attributes and elements for the purpose of achieving internal and external coherence, other wise known as fit, and for information sharing facilitation. Aaen's (2002) position that software development is a "highly complex undertaking characterized by strong interdependencies among tasks and uncertainties" (p. 380) points to the fact that software development organizations also require organizational fits that reinforce information processing across various organizational levels. Consequently, studies by Pourkomeylian (2006) and Halloran (2004) provided insights into how SPI can be hampered by knowledge creation and management capability of software development organizations.

Very close to the assessment of organizational design impact on SPI are the research emanating on organizational learning. Fiol and Lyles (1985) defined organizational learning as "the process of improving actions through better knowledge and understanding" (p. 803). SPI research that conceptualizes SPI as organizational learning, that is, the process of improving actions through knowledge and understanding, have therefore continued to increase over the years. SPI research that adopted organizational learning perspective is pointing to the fact that organizational learning literature can provide a variety of insights into ways organizational design and knowledge management can be maximized to positively impact process improvement programs in software development organizations (Pham and Swierczek, 2006). Huber's (1991) work on organizational learning is one of the most formidable in the field as it assessed different academic fields' contributing to organizational learning literature, its evolution and the limitations inherent in evolving organizational learning research. Huber recognized and articulated four constructs, namely, knowledge acquisition, information distribution, information interpretation, and organizational memory, as those very fundamental to learning organizations. Interestingly, only one of the four constructs articulated by Huber can be referred to as concrete due to the nature of technology based information distribution exemplified by gadgets such as computers and mobile devices such as iPods, phones, etc. The other constructs are soft in nature: information acquisition, interpretation and memory.

Martinez-Leon and Martinez-Gracia's (2011) study provided further insight into the position being propagated in this paper. In explaining the purpose of their research, the duo wrote that their aim "is to determine what type of organizational structure that provides appropriate conditions for the development of organizational learning" (p. 537). The summary of their findings is as stated below:

The framework makes clear that organizational learning varies according to the kind of structure (organic and mechanistic). The study of the different design variables (specialization, formalization, autonomy, centralization and indoctrination) allows us to deepen our understanding of different organizational learning implications. (p. 357) 
The findings above show that Ngwenyama and Norbjerg's (2010) call for research on intraorganizational alliances in software development organizations is timely and relevant and also opens an avenue for SPI researchers to address the limitations that may have impaired the outcomes of SPI research as a result of the non-inclusion of corporate ideology and organizational design as variable influencing SPI program outcomes. In another research that dealt with change management in SPI situations, Mathiassen et al. (2005) advised that "software managers must appreciate that each SPI initiative is unique and carefully negotiate the context of change. Managers must also understand the elements of change involved. SPI can not succeed without management commitment and a mastery of appropriate change tactic" (p. 84). (Italics is ours). We argue that management commitment is a function of corporate ideology and organizational design and interpret appropriate change tactic as that that begins from ideology setting through organizational design that put into cognizance flexibility requirements for SPI practices, to well conceived and implemented quality and performance management. Within the ambit of our argument we acknowledge the limitations inherent in the works cited which interprets the influence of organizational structure on organizational learning primarily from processes process point of view thereby leaving out important variables-corporate ideology and organizational design, work systems and practices. Including corporate ideology and organizational design in SPI research can provide avenues for developing research questions which will allow researcher to reflect on questions regarding intra-organizational alliances among staff and sub-units with regards to knowledge sharing and learning.

However, authors such as Checkland (1981), Beers (1981) and Hoebeke (2000) have come up with the idea of work systems as the most viable way of assessing the challenges organizations face with regards to ensuring high performance. Their arguments are built around the fact that organizational structures are too large to provide a meaningful understanding of what goes on and wrong with elements of work. This school of thought builds its arguments on systems thinking, and therefore incorporates stakeholders who may not be on an organization's payroll as consisting a part of the work systems. They argued that this allows organization analyst to understand human part of work within heterogeneous work contexts. Cappelli and Rogovski (1994) added their voices to the systems based approach to organizational analysis by submitting that new work systems must put into cognizance the psychological and social needs of the workers in relationship with the jobs they do and not primarily the production system and the organization. Such psychological and social need was articulated by Brown and Duguid (1991) in an ethnographic study they carried out to unify the view of working, learning and innovation. Oakland and Oakland (2001) developed a list that include effective communication and team work, planned training and development, strategic alignment of human resource management policies, empowerment of employees and review and continuous improvement as activities that constitute people management in high performing organizations . Kling (1995) and Zacharatos, Boynton, and Jacobs (2005) identified factors such as information, skills, incentives, and responsibility to make decision by workers as part of the elements of high performing work systems. In other to confirm the practical implications of the work system approach Way (2002) did a study which he used to confirmed that work systems have positive impact on the performances of small businesses in the US. We, however, note that despite the fact that SPI programs are change programs that have been impacted by work system factors that there is an obvious limited use of theories and concepts available in the work systems literature by SPI researchers. We agree that IS based SPI research and practice have a lot to learn from, and to contribute to the work systems literature.

Close to the issue of work systems with regards to organizational design and structure are evolutionary management approaches, namely, top-down and bottom-up management approaches. The two approaches are very closely aligned with knowledge flow and structure of authority inherent in an organization. Smeds, Haho, and Alvesalo (2003) did a study that looked at change management in two diverse settings, pharmaceutical and telecommunications, where both top-down and 
bottom-up change management approaches were used. They agreed that the two approaches worked well in their case study organizations because of the dialogue which the change management program initiated between strategy and operations. The argument that is normally raised against the top-down evolutionary management approach is that it does not put into cognizance process issues that are inherent at the operational level due to the difficulty associated with organizational communication between the strategic and operational levels (Jorgensen, 2004). Figure 4 shows a hypothetical example of distorted knowledge flow in two contexts which results because of hierarchical organizational design. The figure shows that while it was easy for close levels, strategic and tactical levels on the one hand, and tactical and operational levels on the other hand, to transfer knowledge it was difficult for both strategic and operational levels to transfer knowledge clearly. Figure 4 further shows that knowledge transfer was broken and unclear between strategic management level and operational management level and verse versa. This anomaly which can only be solved by appropriate organizational design, especially as described by James (2003) of learning organizations, is also evident in software development organizations and affects the ways SPI practices are supported and used as knowledge generating programs. Adopting James (2003) position will mean that practices, not processes must be intertwined at all management levels.

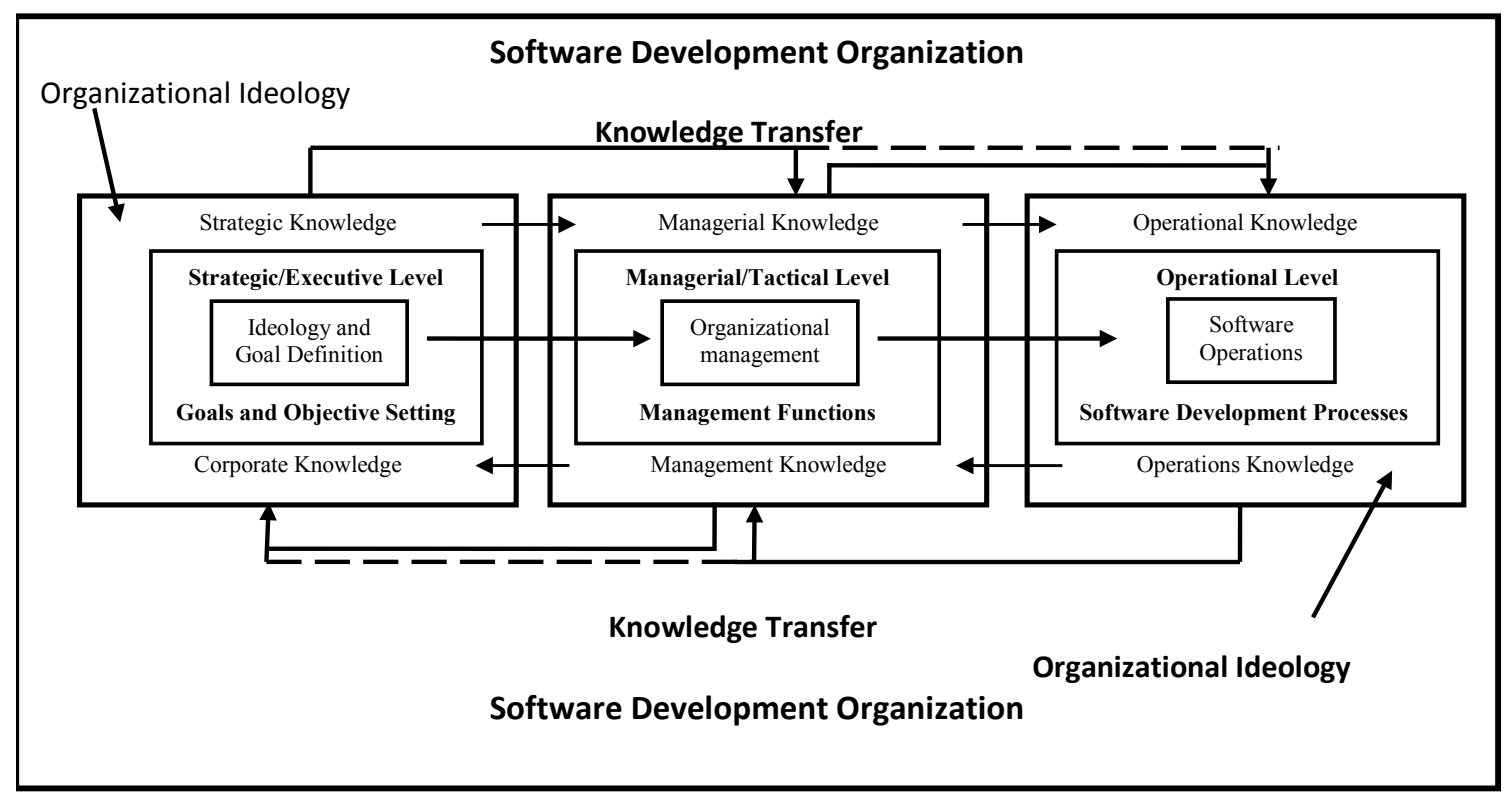

Figure 4: Dynamics of Organizational Knowledge Transfer

Literature covering quality management has also tried to render solutions to challenges that are faced by organizations seeking to improve on their performances at various organizational levels. The philosophy underlying quality management was derived from Deming's 14 point management method and is aimed at changing organizational infrastructure and cultural systems (Anderson, Rungtusanatham, \& Schroeder, 1994; Dean \& Bowen, 1994). Hence, Sousa and Voss (2002) referred to quality management as management philosophy that is meant to impact on principles, practices, and processes. In other words, quality management is a process that assesses corporate ideology and organizational design using knowledge management as its lens. Sousa and Voss' review of the literature on quality management showed that the major dimension of quality management practices available in the literature assessed top management support, top management commitment, visionary leadership, executive commitment, and the role of management. Sousa and Voss concluded that these dimensions dealt with core subjects such as process 
flow management, SPC usage, process management, and process improvement. Invariably the literature has also indicated that strategy, organizational designs, and organizational context influence quality management. Here again, corporate ideology, which is expressed in the form of strategic approaches, is used to lay the foundation for appropriate design of organizations for the attainment of quality objectives. Quality management allows for objective assessment of quality performances across various organizational layers and levels in manner that make performance assessment go beyond operations information strategy (Germain \& Spears, 1999; Moreno-Luzon $\&$ Peris, 1998). Earlier we have conceptualized that the knowledge economy influences the ways contemporary corporate ideologies are shaped. Hence, contemporary quality management claims that quality must be based on accurate knowledge of processes and product quality.

Although quality management has been generally accepted to be a management approach or philosophy, the literature has helped to unfold the controversies that trail organizations attempting to implement quality management. Identified quality management controversies result because of existing alternative organizational elements, such as personnel, processes, capabilities, customers, and, products, that are within and outside the organization implementing quality performance programs (Rust et al., 2002). For instance, a firm might choose customers as the strategic alternative for implementing its quality program. In other words, such a firm might have to improve on its customer care, capability to determine customers' needs and wants, and also develop business strategies that will help it meet customers' value and quality proposition. According to Powell (1995), other alternative strategic choices may include personnel, work processes, and competitive benchmarking. Whatever strategic choice a firm makes, the onus falls on it to use it to develop a quality management strategy that will drive how it will increase revenue, decrease cost of operations, and achieve its immediate and long term business objectives. Although quality management alternative choices include personnel, SPI literature rarely focuses on SPI programs that are primarily directed towards meeting personnel wants and needs. For example in our review of the evolution of SPI, only Inversen and Ngwenyama (2006) made reference to SPI evolution as a result of the need for improving software engineering skills. This is despite the fact SPI literature is beginning to forge new criticism about how software development organizations' work contexts requires appropriate social cohesion and structures that impact on their work systems (Adolph, Kruchten, \& Hall, 2012).

However, performance management literature has come of age and, therefore, seems to proffer solutions to the challenges quality management strategic factors pose to organizations implementing quality management programs. This seeming solution may therefore, be of immense value to IS based SPI researchers (Bititci, Turner, \& Begemann, 2000; Bourne, Franco, \& Wilkes, 2003; Nudurupati, Bititci, Kumar, \& Chan, 2011). With its evolutionary transformation from finance based performance management through shareholders based performance management to stakeholder-centric performance management, performance management literature seems to indicate that quality management strategic choice is at its best when it puts both internal and external stakeholders as strategic quality management elements. In other word, quality management plans, policies and programs should be built around both internal and external stakeholders (Kaplan \& Norton, 1996; Neely et al., 2001; Neely, Gregory, \& Platts, 2005) and not just on one quality element such as personnel or process or capability. Neely et al. (2005) reviewed performance measurement system literature and identified four primary measures, namely, quality, time, flexibility, and cost, that are used for building performance measurement systems adopted by SMEs in the US. In another instance, Alfaro et al.'s (2009) listed eight characteristics of performance measures (business process representation, business process measurement, business process lifecycle management, intra and inter organizational levels measurement, process decomposition approach, intra-inter-process connection management, inter-organizational coordination measurement, and common inter-organizational strategy) that are considered when designing performance measurement systems in collaborative business environments. Neely et al.'s (2005) and 
Alfaro et al.'s (2009) characteristics of performance management measures can help in refocusing SPI programs from its dogmatic focus on processes to include other factors that are beyond process assessment and improvement.

Kaplan and Norton (1992) also advised that the performance of a firm would be ensured in the long term if it can base its performance assessment on the following four key elements: customer perspective, internal business perspective, innovation and learning perspective, and financial perspective. In other word, a firm should aim at performing high on measures such as customer satisfaction, development and implementation of internal business processes that support free flow of work, information and knowledge, innovativeness and learning, and ensuring that activities required to improve revenue and business cost reduction are implemented. According to Neely et al. (2001) a basic performance management question that would allow the development and implementation of viable performance measures is, "What are the needs and wants of stakeholders?" This question seems to have an all encompassing ability to solve organizational problems because of its incorporation of all identified stakeholders such as business owners, managers, personnel, customers, the environment, government and society. It aligns with the dependent variables (requirements, project, product, company, and society) (Gorschek \& Davis, 2008) that software engineering researchers should pay attention to when analyzing SPI factors. Hence, if the question is properly assessed and answered, the question could aid in forming and implementing a corporate objective. Such corporate objective will help develop corporate ideology that will ensure that a firm performs highly with regards to each stakeholder's wants and needs. This stance corroborates Perrini and Tencati's (2006) submission that the stakeholder view of the firm ensures sustainability and achievement of strategic goals.

\section{Discussion of Themes from Grounded Theory Literature Review}

One major problem we have observed in the SPI literature is its slowness to adopt a broad thinking that would incorporate necessary organizational factors into the assessment of SPI programs risks, successes and failures. We assume that this may have arisen because of the foundation of the engineering discipline where pioneers SPI researchers who did not want to look beyond process engineering emerged from. However, with IS researchers showing continuous interest in identifying and analyzing IS phenomena in SPI programs, we assume that the time has come for a thinking pattern that would bring together knowledge available in various sciences dealing with organization, management, IS, and engineering in identifying, analyzing, and understanding SPI phenomena. This is shown in the constructs that make up the model presented in Figure 5. Figure 5 can help to identify the array of academic disciplines whose theories must be concatenated to have a better understanding of SPI and maturity issues in software development organizations. The proposition is not new, however, Paulk et al.'s (1994) descriptions of immature and mature software organizations shows that the attainment of maturity by software development organizations goes beyond process analysis alone. The descriptions are presented thus:

In an immature organization, there is no objective basis for judging product quality or for solving product or process problems. There is little understanding of how the steps of the software process affect quality, and product quality is difficult to predict...customers has little insight into the project until delivery. (p. 7)

A mature software organization, in contrast, possesses an organizationalwide ability for managing software development and maintenance processes. It accurately communicates the software process to both existing and new employees, and carries out work activities according to planned 


\section{process...there is broad-scale, active involvement across the organization} in improvement acvities. (p.7) (emphasis is ours)

What we are advocating is a conceptual shift in which all necessary variables must be brought together and used to assess software development organizations' capability and SPI programs, not the present conceptual framework where they are separately studied. This difference between our proposition for a wide SPI scope, and Iversen, Mathiassen, and Nielsen's (2004) postulation is our inclusion to the variables we consider as necessary for carry out both organizational level and operational level SPI analysis.

One of the major limitations in the claim made by Paulk and his colleagues (1994) together with that of Chrissis, Konrad, and Shrum (2007) when trying to justify the impact CMM and CMMI can play during SPI program was that they laid more emphasis on processes than other possible variables such as personnel and customers. While they may claim that emphasis laid on processes can impact on personnel and customers, we argue that this may have led to the limitation of CMM based process improvement programs which have constantly remained bogus and not impacting efficiently and effectively on work systems and actual practices. The CMM, CMMI, and other normative SPI models present process as if it is the primary means to the ends (profitability, predictability, better work systems, practice evaluation, and the satisfaction of stakeholders' wants and needs) software development organizations seek to attain. We have seen, based on selected literature, that knowledge economy, corporate ideology, organizational design, work systems, quality management, and performance management are all confounding variables in software development organizations' maturity and SPI goals attainment. In fact, the themes that dominated our presentation of the positions available in the literature showed that there is a solid acknowledgment that the knowledge economy affects the setting of corporate objectives and ideologies. It, therefore, follows that we need to start to ask questions on how software development organizations' corporate ideologies are shaped to meet contemporary corporate objective setting, organizational design, quality management, and performance management. We have, through the grounded theory literature review, seen that organizational design measures are influenced by both knowledge economy and corporate ideology. One important thing that is not so loud in the literature is that stakeholders' willingness to access and use information, either for or against, an organization led to the philosophies (quality and performance) that underpin quality and performance management practices in contemporary organizations. With the influx of communication technologies and social media, stakeholders' perception about an organization and their products and services are easily shared across unprecedented physical and technological spaces. Also this scenario has a prominent role to play in the ways stakeholders perceive and value information regarding corporate entities as most people now know that they should request for and use information concerning corporate entities' abilities to meet their value and quality proposition. 


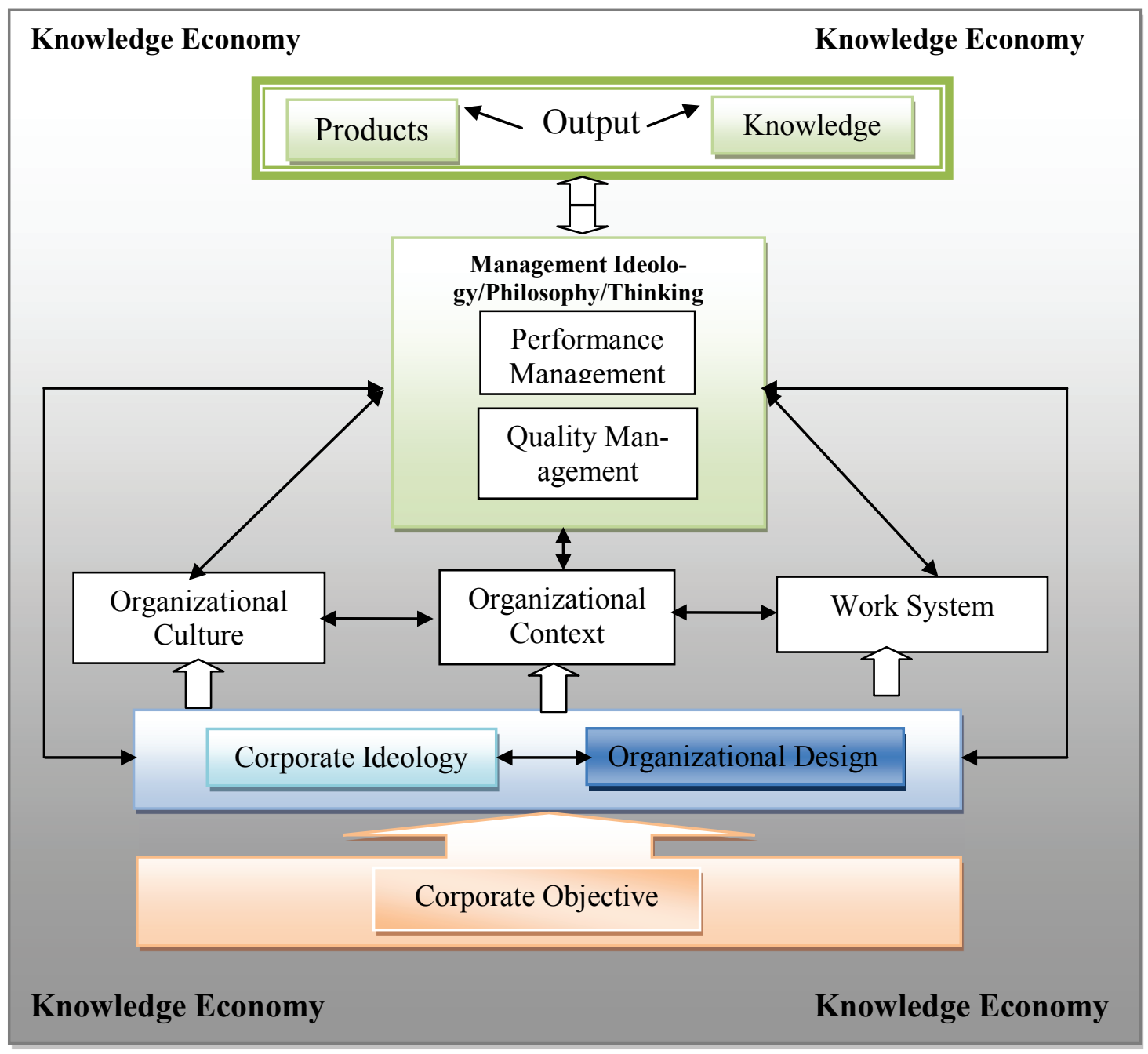

Figure 5: Elements of Software Development Organizations

It is clear, at least beyond what was known before this research, that the relationship between knowledge economy, corporate ideology, organizational design, quality and performance management and software development organizations is very important to assessing software development organizations capabilities and SPI programs. We, therefore, present them as constructs that can be concatenated to produce a model for assessing software development organizations' maturity and factors that lead to the emergence of SPI risks. Interestingly, we developed the constructs into a model that presents software development organizations as organizations which are open systems that are influenced by both their external and internal environments. This opens up the avenue for IS researchers to assess software development organizations from a holistic perspective. Also important is the fact that our conceptual shifts present these constructs as interwoven constructs. This is represented by the double arrows in Figure 5 which show that they influence one another in the actual practical sense. The separation shown in the Model results because of the need for classification and clear visual presentation. 


\section{Systematic Literature Review Methodology}

The Systematic Literature Review (SLR) was adopted as a complimentary methodology for this study. Five of the eleven journals listed as high impact IS journals by the Department of Information Systems, University of Cape Town, South Africa, and the Association of Information Systems' Electronic Library (AISEL) were selected as the sources of the literature to be systematically reviewed. The decision to select five IS journals was reached as a result of the need to ensure that the SPI research reported in selected research articles is strictly based on IS methods and approaches. The five IS journals are the European Journal of Information Systems (EJIS), MIS Quarterly (MISQ), Information Systems Research (ISR), Information Systems Journal (ISJ) and he Journal of Management Information Systems (JMIS). JMIS, however, did not have an advance search interface and, hence, could not provide a search interface that was required to support the search strategy adopted for this research and was as result dropped from the five selected IS journals. The sixth source of the articles reviewed, that is, the Association for Information Systems Electronic Library (AISEL) provided access to conference papers and journal articles on IS based SPI research. However, one of the papers downloaded from AISEL was a duplicate of the paper downloaded from MISQ; it was therefore sieved out from AISEL entries. Consequently, the journal articles and conference papers retrieved for this SLR are shown in the Table below:

Table 1: Sources of Reviewed Articles

\begin{tabular}{|l|l|l|l|}
\hline S/N & Sources & No. of Paper & $\begin{array}{l}\text { No. Available } \\
\text { for Use }\end{array}$ \\
\hline 1. & EJIS & 2 & 1 \\
\hline 2. & ISJ & 1 & 1 \\
\hline 3. & ISR & 1 & 1 \\
\hline 4. & MISQ & 1 & 1 \\
\hline 5. & AIS Electronic Library & 11 & 10 \\
\hline 6. & Total No. of Papers & 16 & 14 \\
\hline
\end{tabular}

Figure 6 shows the SLR process that was followed in the study.

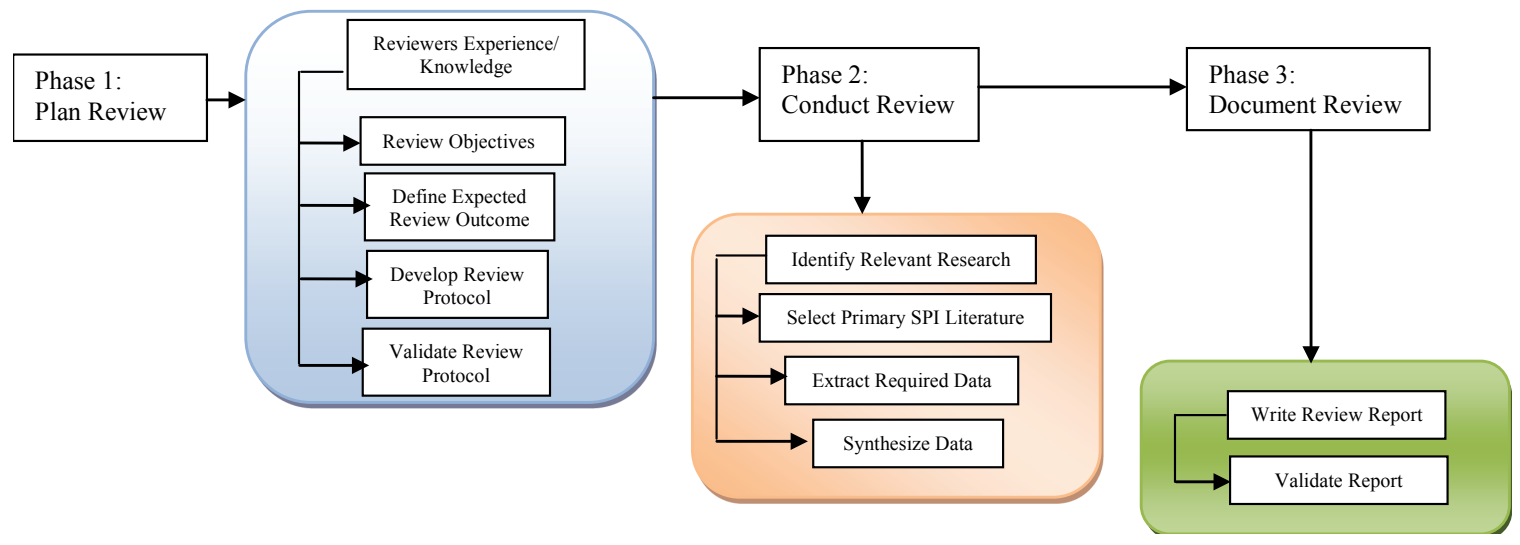

Figure 6: Systematic Literature Review Process

\section{Search Strategy and Selection Criteria}

In order to have high precision and high relevant retrieval rates, we entered the search term "software process improvement" into the advanced search interface of each of the selected journals. We did this by first visiting each of the journal's website where the link to advance search is made available. Each of the selected journals' website had an advanced search interface that 
provided for a space where exact title or exact term can be entered. The space also had a control menu with an option that allowed us to determine that all key terms (software, process, and improvement) should appear in the title. Hence, papers that were retrieved had the three key words in their titles. This allowed us to achieve a low retrieval rate with high precision and high relevance rates. It also allowed the search term to return all articles that have the term "software process improvement" as part of the titles of the papers retrieved. We assume that an article that has "software process improvement" as part of its title would definitely deal with SPI, unlike those that may have dealt specifically with software engineering but included software process improvement as part of their key words. Hence, we adopted the term software process improvement as search term as a way of achieving a high relevant search return rate. We acknowledge that other terms such as 'software engineering,' 'software process engineering,' etc. can be used to retrieve papers on software process improvement but we agreed to use 'software process improvement' based on experience gained from the trial search conducted on each of the websites of the journals selected. However, since AISEL comprises both peer-reviewed and non-peer reviewed papers, its own search interface provided a check point where we indicated that the records we wanted it to retrieve are only peer-reviewed papers. Consequently, all the IS papers on SPI that were reviewed are peer-reviewed. The selection criteria used for selecting the articles that were systematically review was that they must be published in an IS owned research publication outlet, they must have been published between 1991 and 2012, and they must have the noun phrase "software process improvement" in their titles. The search strategy is shown in Figure 7.

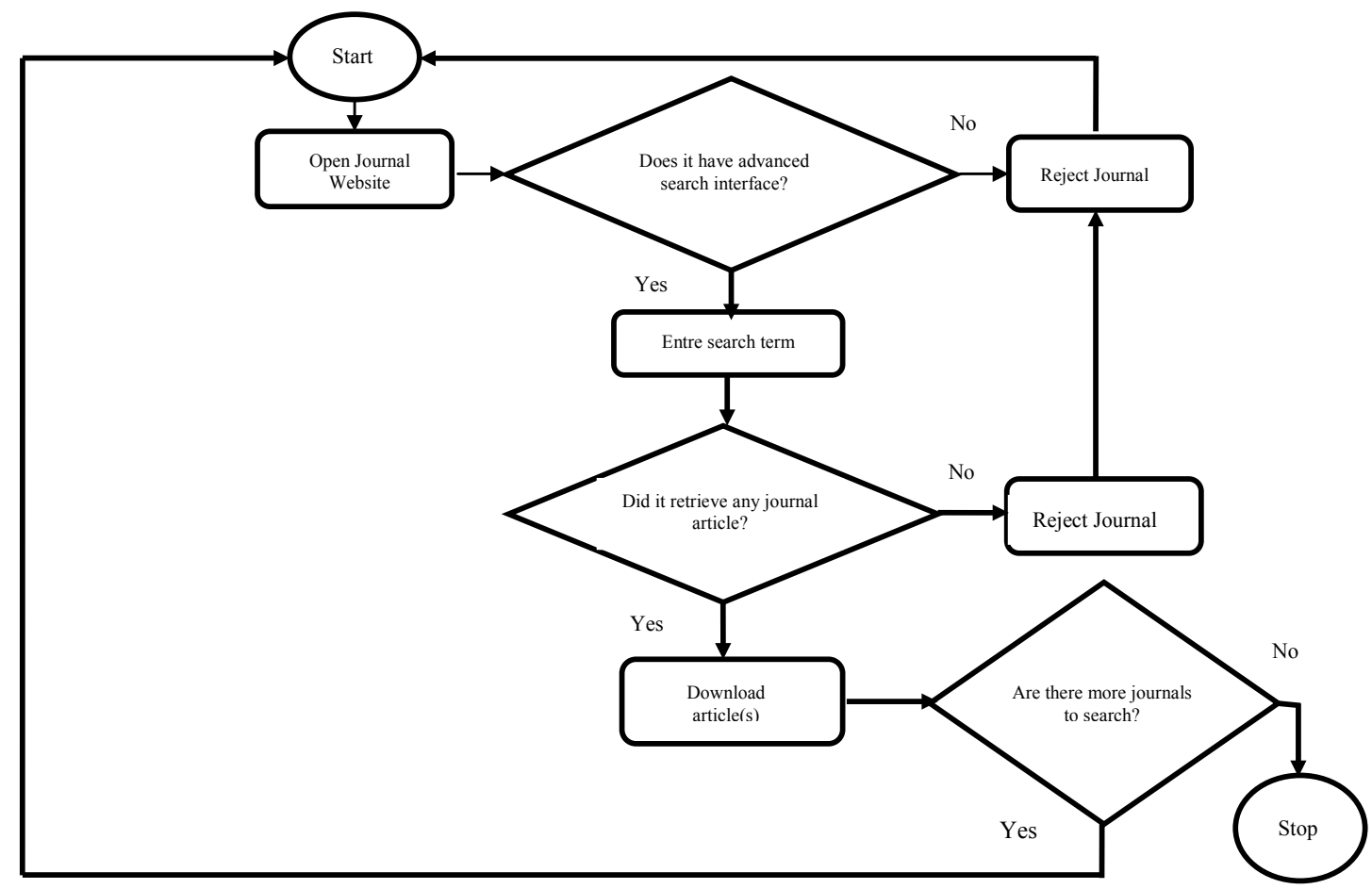

Figure 7: Search Strategy Chart

\section{Data Extraction}

In other to be able to extract the data from the 14 IS research papers downloaded for the study we designed and used a data extraction form. The data extraction form comprised of data extraction entities which include the following: types of authorship, types of paper, key words in the title of articles, research methodology adopted in the papers, contexts or settings where research was 
conducted, SPI framework studied, theoretical framework(s) adopted, and the coverage of variables identified through the grounded theory literature review method, namely, knowledge economy, corporate ideology, organizational design, quality, and performance management. As a way of explanation, we decided to assess types of authorship (single or multiple) and disciplinary collaboration in order to be able to ascertain those that contributed SPI articles to the selected core IS journals. This has an implication of showing if academics from other disciplines also used IS journals as outlets to disseminate their research on SPI or if they collaborated with IS researchers. Key words in articles were instrumental in identifying key subject areas that were treated together with SPI issues. Also, research methodologies and theoretical framework adopted by authors of the papers were assessed to see if they aligned with those already known and used by IS researchers. It is known that IS strives to study IT, people, and organization, consequently, data extracted on research contexts or setting provides information on whether IS research is on people or on organizational or on society at large. The assessment of SPI frameworks studied by IS researchers was used to understand which of the formal SPI framework was studied more by IS researchers and also to see if IS SPI research was conducted without consideration for formal SPI frameworks such CMM, CMMI, SPICE, etc. In conclusion, we had developed arguments about the implications of the knowledge economy on contemporary organizations, including software development organizations. We argued that SPI research carried out by researchers in disciplines other than IS did not pay adequate attention to the implication of the knowledge economy, corporate ideology, organizational design, quality management, and performance management on SPI implementation. Hence, we also adopted these variables as properties to be assessed in the systematic literature review to see if IS researchers paid required attention to them as factors that impact on the management of SPI risks and attainment of SPI goals in software development organizations.

\section{Systematic Literature Review Results}

We did a descriptive review of the fourteen documents that were retrieved in two segments titles author description and content description. The results are presented in Table 2:

Table 2: Description of the Authors of Reviewed Articles

\begin{tabular}{|c|c|c|c|c|c|}
\hline $\begin{array}{l}\text { Paper } \\
\text { No. }\end{array}$ & Authors Names & $\begin{array}{l}\text { Type of Author- } \\
\text { ship }\end{array}$ & $\begin{array}{l}\text { No. of Au- } \\
\text { thors }\end{array}$ & Authors' Disciplines & $\begin{array}{l}\text { Type of } \\
\text { Paper }\end{array}$ \\
\hline 1 & Kautz and Nielsen (2004) & Multiple & 2 & $\begin{array}{ll}\text { 1. } & \text { Informatics } \\
\text { 2. } & \text { Computer Science }\end{array}$ & $\begin{array}{l}\text { Journal } \\
\text { Article }\end{array}$ \\
\hline 2 & Iversen, Mathiassen, and Nielsen (2004) & Multiple & 3 & $\begin{array}{ll}\text { 1. } & \text { Business Administration } \\
\text { 2. } & \text { Process Innovation } \\
\text { 3. } & \text { Computer Science }\end{array}$ & $\begin{array}{l}\text { Journal } \\
\text { Article }\end{array}$ \\
\hline 3. & Jorgensen and Sjoberg (2001) & Multiple & 2 & $\begin{array}{ll}\text { 1. } & \text { Informatics } \\
\text { 2. } & \text { Not shown } \\
\end{array}$ & $\begin{array}{l}\text { Journal } \\
\text { Article }\end{array}$ \\
\hline 4. & $\begin{array}{l}\text { Aaen, Arent, Mathiassen, and Ngwenyama } \\
(2001)\end{array}$ & Multiple & 4 & $\begin{array}{ll}\text { 1. } & \text { Computer Science } \\
\text { 2. } & \text { Computer Science } \\
\text { 3. } & \text { Computer Science } \\
\text { 4. } & \text { Computer Science } \\
\end{array}$ & $\begin{array}{l}\text { Journal } \\
\text { Article }\end{array}$ \\
\hline 5. & Abrahamsson (2001) & Single & 1 & $\begin{array}{lll}\text { 1. } & \begin{array}{l}\text { Information } \\
\text { Science }\end{array} & \text { Processing } \\
\end{array}$ & $\begin{array}{l}\text { Journal } \\
\text { Article }\end{array}$ \\
\hline 6. & Kautz (2001) & Single & 1 & 1. Informatics & $\begin{array}{l}\text { Journal } \\
\text { Article }\end{array}$ \\
\hline 7. & Kautz, Hansen, and Thaysen (2001) & Multiple & 2 & $\begin{array}{ll}\text { 1. } & \text { Informatics } \\
\text { 2. } & \text { Not shown }\end{array}$ & $\begin{array}{l}\text { Journal } \\
\text { Article }\end{array}$ \\
\hline 8. & Slaughter and Kirsch (2006) & Multiple & 2 & $\begin{array}{ll}\text { 1. } & \text { Business Management } \\
\text { 2. } & \text { Business Management }\end{array}$ & $\begin{array}{l}\text { Journal } \\
\text { Article }\end{array}$ \\
\hline 9. & Rodgers (1998) & Single & 1 & 1. Not shown & Proceeding \\
\hline 10. & Hardgrave, Taylor, and Kidd (2000) & Multiple & 3 & 1. Not shown & Proceeding \\
\hline 11. & Harter, Slaughter, and Krishnan (1998) & Multiple & 3 & $\begin{array}{ll}\text { 1. } & \text { Not shown } \\
\text { 2. } & \text { Not shown } \\
\text { 3. } & \text { Not shown } \\
\end{array}$ & Proceeding \\
\hline 12. & Pourkomeylian (2006) & Single & 1 & 1. Information Technology & Proceeding \\
\hline 13. & Aaen (2002) & Single & 1 & 1. Computer Science & Proceeding \\
\hline 14. & Neilsen and Ngwenyama (2002) & Multiple & 2 & $\begin{array}{ll}\text { 1. } & \text { Computer Science } \\
\text { 2. } & \text { Information Systems }\end{array}$ & Proceeding \\
\hline
\end{tabular}


Invariably, the IS field has many sister tags, such as informatics, IT and business, information technology, information processing science, and informing science. This reflects in Table 2 where none of the authors indicated that their academic discipline is information systems. However, the nature of authorship of IS based SPI research is mostly multiple authorship which shows a couple of combination of authors from different disciplines. A good example is the combination of authors from the business management, computer science, and process innovation academic fields. This kind of collaboration, although not so profound in this particular study, is the one that we are hoping will encourage the development of variable relationship that will further allow IS research to deeply scrutinize software development organizations and how they should manage SPI risks.

Table 3: Description of the Contents of Reviewed Articles

\begin{tabular}{|c|c|c|c|c|c|c|c|}
\hline $\begin{array}{l}\text { Pa- } \\
\text { per } \\
\text { No. }\end{array}$ & $\begin{array}{l}\text { Keywords in } \\
\text { Titles }\end{array}$ & $\begin{array}{l}\text { Keywords Pro- } \\
\text { vided by Authors }\end{array}$ & $\begin{array}{l}\text { Methodology } \\
\text { and Approach }\end{array}$ & $\begin{array}{l}\text { Theoretical } \\
\text { Background }\end{array}$ & Model & $\begin{array}{l}\text { Research } \\
\text { Setting }\end{array}$ & $\begin{array}{c}\text { Coverage of } \\
\text { Variables }\end{array}$ \\
\hline 1. & $\begin{array}{ll}\text { 1. } & \text { SPI } \\
\text { 2. } & \text { SPI Imple- } \\
\text { mentation } \\
\text { 3. SPI Innova- } \\
\text { tion } \\
\text { 4. Organiza- } \\
\text { tions }\end{array}$ & $\begin{array}{ll}\text { 1. } & \text { SPI } \\
\text { 2. } & \begin{array}{l}\text { Organiza- } \\
\text { tional Im- } \\
\text { plementation }\end{array} \\
\text { 3. } & \begin{array}{l}\text { Process In- } \\
\text { novation }\end{array} \\
\text { 4. } & \begin{array}{l}\text { Organiza- } \\
\text { tional Devel- } \\
\text { opment }\end{array}\end{array}$ & Action Research & $\begin{array}{l}\text { Slappendel } \\
\text { (1996) Innova- } \\
\text { tion Framework }\end{array}$ & None & $\begin{array}{l}\text { Organiza- } \\
\text { tion }\end{array}$ & $\begin{array}{l}\text { Organiza- } \\
\text { tional Design }\end{array}$ \\
\hline 2. & $\begin{array}{ll}\text { 1. } & \text { Managing } \\
\text { Risk } \\
\text { 2. SPI } \\
\text { 3. Action } \\
\text { Research }\end{array}$ & $\begin{aligned} & \text { 1. } \text { Risk Man- } \\
& \text { agement } \\
& \text { 2. } \text { SPI } \\
& \text { 3. } \text { Action Re- } \\
& \text { search } \\
& \text { 4. } \\
& \text { Collaborative } \\
& \begin{array}{l}\text { Practice Re- } \\
\text { search }\end{array}\end{aligned}$ & $\begin{array}{ll}\text { 1. } & \text { Collabora- } \\
\text { tive Practice } \\
\text { Research } \\
\text { 2. Action Re- } \\
\text { search }\end{array}$ & $\begin{array}{l}\text { Risk Manage- } \\
\text { ment }\end{array}$ & & $\begin{array}{l}\text { Organiza- } \\
\text { tion }\end{array}$ & None \\
\hline 3. & $\begin{array}{l}\text { 1. SPI } \\
\text { 2. Human } \\
\text { judgment } \\
\text { 3. Heuristics }\end{array}$ & $\begin{array}{l}\text { 1. SPI } \\
\text { 2. Human Judg- } \\
\text { ment Heuristics } \\
\text { 3. Expert Judg- } \\
\text { ment } \\
\text { 4. Software Effort } \\
\text { Estimation }\end{array}$ & $\begin{array}{l}\text { 1. Experimental } \\
\text { Research }\end{array}$ & Heuristics & None & $\begin{array}{l}\text { Organiza- } \\
\text { tion }\end{array}$ & None \\
\hline 4. & $\begin{array}{l}\text { 1. MAP- Man- } \\
\text { agement, Ap- } \\
\text { proach, Per- } \\
\text { spective } \\
\text { 2. SPI } \\
\end{array}$ & $\begin{array}{l}\text { 1. Strategic Man- } \\
\text { agement } \\
\text { 2. SPI }\end{array}$ & $\begin{array}{l}\text { Literature Re- } \\
\text { view }\end{array}$ & $\begin{array}{l}\text { MAP- Manage- } \\
\text { ment, Approach, } \\
\text { Perspective }\end{array}$ & None & & $\begin{array}{l}\text { Strategy- } \\
\text { Corporate } \\
\text { Ideology }\end{array}$ \\
\hline 5. & $\begin{array}{l}\text { 1. Commitment } \\
\text { 2. SPI }\end{array}$ & $\begin{array}{l}\text { 1. Commitment } \\
\text { 2. Forms of } \\
\text { Commitment } \\
\text { 3. Commitment } \\
\text { Models } \\
\text { 4. Misconcep- } \\
\text { tions }\end{array}$ & $\begin{array}{l}\text { Literature Re- } \\
\text { view }\end{array}$ & $\begin{array}{l}\text { Commitment } \\
\text { Model }\end{array}$ & None & & None \\
\hline 6. & $\begin{array}{l}\text { 1. SPI Research } \\
\text { 2. Scandinavia }\end{array}$ & Not shown & $\begin{array}{l}\text { Review of Con- } \\
\text { tribution (Edito- } \\
\text { rial) }\end{array}$ & None & None & & None \\
\hline 7. & $\begin{array}{l}\text { 1. Software } \\
\text { Organizations } \\
\text { 2. SPI Perspec- } \\
\text { tives } \\
\text { 3. SPI }\end{array}$ & Not shown & Action Research & $\begin{array}{l}\text { Scientific Re- } \\
\text { search Paradigms }\end{array}$ & $\begin{array}{l}\text { 1. } \mathrm{CMM} \\
\text { 2. IDE- } \\
\text { AL }\end{array}$ & & $\begin{array}{l}\text { Organization } \\
\text { Design }\end{array}$ \\
\hline
\end{tabular}




\begin{tabular}{|c|c|c|c|c|c|c|c|}
\hline $\begin{array}{l}\text { Pa- } \\
\text { per } \\
\text { No. }\end{array}$ & $\begin{array}{l}\text { Keywords in } \\
\text { Titles }\end{array}$ & $\begin{array}{c}\text { Keywords Pro- } \\
\text { vided by Authors }\end{array}$ & $\begin{array}{l}\text { Methodology } \\
\text { and Approach }\end{array}$ & $\begin{array}{l}\text { Theoretical } \\
\text { Background }\end{array}$ & Model & $\begin{array}{l}\text { Research } \\
\text { Setting }\end{array}$ & $\begin{array}{c}\text { Coverage of } \\
\text { Variables }\end{array}$ \\
\hline 8. & $\begin{array}{l}\text { 1. Knowledge } \\
\text { Transfer } \\
\text { 2. Knowledge } \\
\text { Transfer Portfo- } \\
\text { lios } \\
\text { 3. SPI }\end{array}$ & $\begin{array}{l}\text { 1. Knowledge } \\
\text { Transfer Mecha- } \\
\text { nism Portfolios } \\
\text { 2. Portfolio Inten- } \\
\text { sity } \\
\text { 3. Portfolio Com- } \\
\text { position } \\
\text { 4. Knowledge } \\
\text { Transfer, } \\
\text { 5. SPI } \\
\text { 6. Management } \\
\text { of Information } \\
\text { Systems }\end{array}$ & Field Study & $\begin{array}{l}\text { 1. Organiza- } \\
\text { tional Design } \\
\text { 2. Knowledge } \\
\text { Transfer }\end{array}$ & None & & $\begin{array}{l}\text { Organiza- } \\
\text { tional De- } \\
\text { sign- } \\
\text { Knowledge } \\
\text { Management }\end{array}$ \\
\hline 9. & $\begin{array}{l}\text { 1. SPI } \\
\text { 2. Feedback } \\
\text { Mechanism }\end{array}$ & Not shown & Survey Research & $\begin{array}{l}\text { Feedback Mech- } \\
\text { anism }\end{array}$ & None & & None \\
\hline 10. & $\begin{array}{l}\text { 1. SPI } \\
\text { 2. Effort Chro- } \\
\text { nology }\end{array}$ & Not shown & $\begin{array}{l}\text { Chronological } \\
\text { Research }\end{array}$ & None & CMM & & None \\
\hline 11. & $\begin{array}{l}\text { 1. SPI Life } \\
\text { Cycle } \\
\text { 2. SPI }\end{array}$ & $\begin{array}{l}\text { 1. Software Qual- } \\
\text { ity } \\
\text { 2. Information } \\
\text { Systems Devel- } \\
\text { opment } \\
\text { 3. Information } \\
\text { Systems Devel- } \\
\text { opment Efforts }\end{array}$ & $\begin{array}{l}\text { Longitudinal } \\
\text { Study }\end{array}$ & $\begin{array}{l}\text { Quality Man- } \\
\text { agement }\end{array}$ & None & & None \\
\hline 12. & $\begin{array}{l}\text { 1. SPI } \\
\text { 2. SPI Strategy }\end{array}$ & $\begin{array}{l}\text { 1. SPI } \\
\text { 2. Strategy } \\
\text { 3. Change }\end{array}$ & $\begin{array}{l}\text { Literature Re- } \\
\text { view }\end{array}$ & $\begin{array}{l}\text { 1. Organization- } \\
\text { al Change } \\
\text { Management } \\
\text { 2. Strategy Pro- } \\
\text { cesses }\end{array}$ & None & & $\begin{array}{l}\text { Strategy- } \\
\text { Corporate } \\
\text { Ideology }\end{array}$ \\
\hline 13. & $\begin{array}{l}\text { 1. SPI } \\
\text { 2. Design } \\
\text { 3. SPI by De- } \\
\text { sign }\end{array}$ & Not shown & $\begin{array}{l}\text { Literature Re- } \\
\text { view }\end{array}$ & $\begin{array}{l}\text { 1. Knowledge } \\
\text { Management } \\
\text { 2. Organization- } \\
\text { al Design }\end{array}$ & None & & None \\
\hline 14. & $\begin{array}{l}\text { 1. Organiza- } \\
\text { tional Influence } \\
\text { Process } \\
\text { 2. SPI }\end{array}$ & Not shown & $\begin{array}{ll}\text { 1. } & \text { Action Re- } \\
\text { search } \\
\text { 2. Field Re- } \\
\text { search }\end{array}$ & $\begin{array}{l}\text { Organiza- } \\
\text { tional Influ- } \\
\text { ence Theory }\end{array}$ & None & $\begin{array}{l}\text { Organiza- } \\
\text { tion }\end{array}$ & $\begin{array}{l}\text { Organiza- } \\
\text { tional De- } \\
\text { sign- } \\
\text { Influence } \\
\text { Process }\end{array}$ \\
\hline
\end{tabular}

As expected because of the search term we adopted, all the 14 IS based SPI research systematically reviewed have the term SPI in their title keywords. Six of the 14 articles did not provide author keywords, while out of the nine articles whose authors provided author keywords only two did not include the term SPI as keyword description for their articles, although the two articles that did not include SPI as authors keywords have the term in their titles. This showed that all the articles reviewed represents IS based SPI research. We say this irrespective of the authors' disciplinary affiliations, since publications in the selected IS research outlets are required to take into cognizance IS methods, approaches, and phenomena. Of importance to this complimentary SLR is the assessment of the inclusion of the five variables (knowledge economy, corporate ideology, organizational design, quality management, and performance management) identified through the grounded theory literature review method into IS based SPI research. Organizational design as variable appeared in three articles. In other word, four of the 14 articles assessed covered the variables and indicate that IS research, as expected, deemed it important to evaluate SPI phenomena in contemporary software development organizations. We noticed that variables such as knowledge economy and performance management were not precisely assessed by all 14 IS based articles evaluated. However, two did study knowledge transfer and management. These two subjects are quite different from the concept of knowledge economy. We have noted that we 
are going to use the SLR to show the extent to which IS based SPI authors treat each of the five confounding variables we identified through the grounded theory literature review method as causal variables impacting SPI practices. However our review shows that the current level of treatment of these confounding variables is low among IS authors. This is despite the role the knowledge economy played in reshaping management thinking and stakeholders' information awareness and management capability and its influence on the emergence and sporadic transformation of management philosophies such as quality and performance management. We know that these variables constitute the present and the future of SPI research as they influence how issues such as work systems, learning, knowledge management, and practices should be viewed within software development organizations.

\section{Recommendations for Future IS Research}

Although this research may not be used to make generalization on the extent to which IS based SPI research viewed the five variables we have identified as confounding variables to software development organizations' capability and SPI program assessment, it does provide commendable and useful details that support its proposition that there should be a conceptual shift in the way software development organizations' capability and SPI programs are researched. The 14 IS based SPI research publications assessed showed very fundamental difference in the subjects treated with regards to SPI. This is due to their recognition of the SPI phenomena as organizational change program and the use of various organizational theories to backup their search for solutions to problems SPI program implementation face. They also addressed management related variables such as risk management, MAP, and quality management. We recommend to the IS research community the need to approach software development organizations research using knowledge economy, corporate ideology, organizational design, quality management, and performance management as causal variables. Only then can we have a holistic view of the variables which may have made the identification of software development organizations' capability to ensure successful SPI elude our knowledge.

This opens up new research areas that can take the form of both positivist and interpretive paradigms. We can begin by first looking at the larger organizational factors like structuring command and power and evaluating evolutionary issues such as top-down and bottom-up approach to management. On the other hand, using the interpretive perspective will allow us focus on intangibles, such as ideologies, and what shapes them, especially among owners of software development organizations. This is actually very fundamental as most software development organizations are SMEs whose owner(s) are easily known, unlike large corporations whose owners are represented by boards and shareholders. Apart from ideology, intangibles like learning, social networks, organizational influence processes, practices among others may also be expanded in the conceptual shift proposed in this study. In other words, IS researchers can begin to find out how these are being impacted, especially by knowledge economy and corporate ideology. This can lead the IS community to producing the required array of knowledge that can aid design science research in which artifacts that can be used to measure software development organizations' capability can be produced.

\section{Conclusion}

Having tried to provide a basis for a conceptual shift in the ways software development organizations' capability to manage SPI programs should be studied and proving that IS SPI researchers have, either consciously or unconsciously started out a journal towards this objective, we can conclude that this may forge a new beginning for fruitful SPI research in the IS community. Being an academic discipline whose primary research claim is to study IT, organizations, and society, IS has grown research methodologies, approaches, and theoretical frameworks that show that 
it has what it takes to provide the breakthrough required to develop capability measures for software development organizations. However, considering the dynamic nature of the current social order we conclude that the proposed conceptual shift will provide another set of conceptual methodological and theoretical challenges to the IS community. We however, make our assurances that IS is capable of pushing this new conceptual shift through.

\section{References}

Aaen, I. (2002). Challenging software process improvement by design. Proceedings of the European Conference on Information Systems. Paper 75. Accessed on November 15, 2012, from http://aisel.aisnet.org/ecis2002/75

Aaen, I., Arent, J., Mathiassen, L., \& Ngwenyama, O. (2001). A conceptual MAP of software process improvement. Scandinavian Journal of Information Systems, 13(1), Article 8. Accessed on November 15, 2012, from http://aisel.aisnet.org/sjil/vol13/issu1/8

Abrahamsson, P. (2001). Rethinking the concept of commitment in software process improvement. Scandinavian Journal of Information Systems, 13, 35-59.

Adolph, S., Kruchten, P., \& Hall W. (2012). Reconciling perspectives: a grounded theory of how people manage the process of software development. The Journal of Systems and Software, 85, 1269-1286.

Alavi, M., \& Leidner, D. (2001). Review: knowledge management and knowledge management systems: Conceptual foundations and research issues. MIS Quarterly, 25(1), 107-136.

Alfaro, J., Rodriguez-Rodriguez, R., Verdecho, M., \& Ortiz, A. (2009). Business process interoperability and collaborative performance measurement. International Journal of Computer Integrated Manufacturing, 22(9), 877-889.

Anderson, J., Rungtusanatham, M., \& Schroeder, R. (1994). A theory of quality management underlying the Deming management method. Academy of Management Review, 19(3), 472-509.

Barclay, C. (1993). Quality strategy and TQM policies: Empirical evidence. Management International Review, 1, 87-98.

Bates, K., Amundson, S., Schroeder, R., \& Morris, W. (1995). The crucial relationship between manufacturing strategy and organizational culture. Management Science, 41(10), 1565-1580.

Beers, S. (1981). The brain of the firm. Hoboken: Wiley Publishers.

Bernroider, E. (2002). Factors in SWOT analysis applied to micro, small-to-medium and large software enterprises: An Australian study. European Management Journal, 20(5), 562-573.

Beyer, J. (1981). Ideologies, values and decision-making in organizations. In P. Nystrom \& W. Starbuck (Eds.), Handbook of organizational design (Vol. 2) (pp. 166-202). New York: Oxford University Press.

Bititci, U., Turner U., \& Begemann, C. (2000). Dynamics of performance measurement systems. International Journal of Operations \& Production Management, 20(6), 692-704.

Blumberg, R. (1987). Organizations in contemporary society. Englewood Cliffs: Prentice-Hall.

Bourne, M., Franco, M., \& Wilkes, J. (2003). Corporate performance management. Measuring Business Excellence, 7(3), 15-21.

Britz, J., Lor, P., Coetzee, I., \& Bester, B. (2006). Africa as a knowledge society: A reality check. The Information and Library Review, 38, 25-40.

Brown, J., \& Duguid, P. (1991). Organizational learning and communities-of-practice: Toward a unified view of working, learning and innovation. Organizational Science, 2(1), 40-57.

Burke, W., \& Litwin, G. (1992). A causal model of organizational performance and change. Journal of Management, 18(3), 523-545. 
Cappelli, P., \& Rogovski, N. (1994). New work systems and skill requirements. International Labour Review, 133(2), 205-220.

Carter, C., \& Roger, D. (2008). A framework of sustainability supply chain management: Moving toward new theory. International Journal of Physical Distribution and Logistic Management, 38(5), 360-387.

Checkland, P. (1981). Systems thinking. Systems practice. Hoboken: Wiley Publishers.

Cho, J., Ozment, J., \& Sink, H. (2008). Logistics capacity, logistics outsourcing and firm performance in an e-commerce market. Information Systems Management, Summer, 336-359.

Chrissis, M., Konrad, M., \& Shrum, S. (2007). CMMI: Guidelines for process integration and process improvement (2nd ed.). Upper Saddle River: Addison-Wesley.

Cutcliffe, J. (2000). Methodological issues in grounded theory. Journal of Advanced Nursing, 31(6), 14761484.

Dean, J., \& Bowen, D. (1994). Management theory and total quality: Improving research and practice through theory development. Academy of Management Review, 19(3), 392-418.

Debou, C., \& Kuntzmann-Combelles, A. (2000). Linking software process improvement to business strategies: experiences from industry. Software Process: Improvement and Practice, 5(1), 55-64.

Drazin, R., \& Van de Ven, A. (1985). Alternative forms of fits in contingency theory. Administrative Science Quarterly, 30, 514-539.

Drucker, P. (1969). The age of discontinuity: guidelines to our changing society. London: Pan Book.

Dyba, T. (2000). An instrument for measuring the key factors of success in software process improvement. Empirical Software Engineering, 5, 357-390.

Evgenou, T. (2002). Information integration and information strategies for adaptive enterprises. European Management Journal, 20(5), 486-494.

Fiol, C., \& Lyles, M. (1985). Organizational learning. The Academy of Management Review, 10(4), 803813.

Galbraith, J. (1974). Organization design: An information processing view. Interfaces, 4(3), 28-36.

Garengo, P., Nudurupati, S., \& Bititci, U. (2007). Understanding the relationship between PMS and MIS in SMEs: An organizational life cycle perspective. Computers in Industry, 58, 677-687.

Gattiker, T., \& Goodhue, D. (2004). Understanding the local-level costs and benefits of ERP through organizational information processing theory. Information and Management, 4(4), 431-443.

Germain, R., \& Spears, N. (1999). Quality management and its relationship with organizational context and design. International Journal of Quality \& Reliability Management, 16(4), 371-392.

Glynn, A., \& Raffaelli, R. (2010). Uncovering mechanisms of theory development in an academic field: lessons from leadership research. The Academy of Management Annals, 4(1), 359-401.

Goll, I., \& Zeitz. (1991). Conceptualizing and measuring corporate ideology. Organization Studies, 12(2), 191-207.

Gorshek, T., \& Davis, A. (2008). Requirements engineering: In search of the dependent variables. Information and Software Technology, 50, 67-75.

Grandori, A., \& Furnari, S. (2008). A chemistry of organization: Combinatory analysis and design. Organizational Studies, 29(3), 459-485.

Halloran, P. (2004). Software process improvement, organizational learning and knowledge management as a multilateral approach to understanding and improving organization capability. Proceedings of the Australian Conference on Information Systems, paper 86. Available at: http://aisel.aisnet.org/acis2004/86 Accessed on November 9, 2012. 
Hambrik, D., \& Mason, P. (1984). Upper echelons: The organization as a reflection of its top managers. Academy of Management Review, 2, 193-206.

Hannola, L., Oinonen, P., and Nukula, U. (2011). Assessing and improving the front end activities of software development. International Journal of Business Information Systems, 7(1), 41-59.

Hardgrave, B., Taylor, A., \& Kidd, J. (2000). The long road to software process improvement: A chronology of one company's effort. Proceedings of the Americas Conference on Information Systems. Paper 425. Accessed on November 15, 2012, from http://aisel.aisnet.org/amcis2000/425

Harter, D., Slaughter, S., \& Krishman, M. (1998). The life cycle effects of software process improvement: A longitudinal study. Proceedings of the International Conference on Information Systems. Paper 36. Accessed on November 15, 2012, from http://aisel.aisnet.org/icis1998/36

Hitt, L., Wu, D., \& Shou, X. (2002). Investment in enterprise resource planning: Business impact and productivity measures. Journal of Management Information Systems, 19(1), 71-98.

Hoebeke, L. (2000). Making works systems better: a practitioner's reflections. Sprouts: Working papers in information systems, l(18). Retrieved from http://sprouts.aisnet.org/1-18

Huber, G. (1991). Organizational learning: The contributing process and the literatures. Organization Science, 2(1), 88-115.

Iversen, J., Mathiassen, I., \& Nielsen, P. (2004). Managing risk in software process improvement: An action research approach. MIS Quarterly, 28(3), 395-433.

Iversen, J., \& Ngwenyama, O. (2006). Problems in measuring effectiveness in software process improvement: A longitudinal study of organizational change at Danske Data. International Journal of Information Management, 26, 30-43.

James, C. (2003). Designing learning organizations. Organizational Dynamics, 23(1), 46-61.

Johnson, M., Christensen, C., \& Kagermann, H. (2008). Reinventing your business model. Harvard Business Review, December, 51-59.

Jorgensen, M. (2004). Top-down and bottom-up estimation of software development effort. Information and Software Development Technology, 46, 3-16.

Jorgensen, M., \& Sjoberg, D. (2001). Software process improvement and human judgement heuristics. Scandinavian Journal of Information Systems, 13 (1), 1-18. Accessed on November 15, 2012, from http://aisel.aisnet.org/sjis/vol13/iss1/2

Kaplan, R \& Norton, D. (1992). The balanced score card: Measures that drive performance. Harvard Business Review, (January-February), 71-79.

Kaplan, R., \& Norton, D. (1996). Using the balanced scorecard as a strategic management system. Harvard Business Review, January-February, 3-13.

Kaplan, R., \& Norton, D. (2000). Having trouble with your strategy? Then map it. Harvard Business Review, September-October, 1-10.

Kautz, K. (2001). Trends in the research of software process improvement in Scandinavian. Scandinavian Journal of Information Systems, 13(1), Article 3. Accessed on November 15, 2012, from http://aisle.aisnet.org/sjis/vol3/iss1/3

Kautz, K., Hansen, H., \& Thaysen, K. (2001). Understanding and changing software organizations: An exploration of four perspectives on software process improvement. Scandinavian Journal of Information Systems, 13(1), Article 4. Accessed on November 15, 2012, from http://aisel.aisnet.org/sjis/vol3/iss1/4

Kautz, K., \& Nielsen, P. (2004). Understanding the implementation of software process improvement innovation in software organizations. Information Systems Journal, 14, 3-22.

Kelly, D., \& Culleton, B. (1999). Process improvement for small organizations. Computers, October, 4147. 
Kisielnicki, J., \& Sobolewska, O. (2010) E-learning as a strategy of acquiring a company's intellectual capital. Interdisciplinary Journal of E-Learning and Learning Objects, 6, 153-174. Retrieved from http://ijello.org/Volume6/IJELLOv6p153-174Kisielnicki690.pdf

Kling, J. (1995). High performance work systems and firm performance. Monthly Labour Review, May, 2936.

Koufteros, X., Nahm, A., Cheng, T., \& Lai, K. (2007). An empirical assessment of Nomological network of organizational design constructs: From culture to structure to pull production to performance. International Journal of Production Economics, 106, 468-492.

Livari, J., \& Huisman, M. (2007). The relationship between organizational culture and the deployment of systems development methodologies. MIS Quarterly, 31(1), 35-58.

Martin, R. (2010). The age of customer capitalism. Harvard Business Review, January-February, 58-65.

Martinez-Leon, I., \& Martinez-Garcia, J. (2011). The influence of organizational structure on organizational learning. International Journal of Manpower, 32(5), 537-566.

Mathiassen, L., Ngwenyama, O., \& Aaen, I. (2005). Managing change in software process improvement. IEEE Software, November/December, 84-91.

Mintzberg, H. (1979). The structuring of organizations. New Jersey: Prentice Hall.

Moitra, D. (1998). Managing change for software process improvement initiatives: A practical experience based approach. Software Process-Improvement and Practice, 4, 199-207.

Moreno-Luzon, M., \& Peris, F. (1998). Strategic approaches, organizational design and quality management: Integration in a fit and contingency model. International Journal of Quality Science, 3(4), 328347.

Naizi, M., Wilson, D., \& Zowghi, D. (2005). A maturity model for the implementation of software process improvement: An empirical study. The Journal of Systems and Software, 74, 155-172.

Neely, A., Adams, C., \& Crowe, P. (2001). The performance prism in practice. Measuring Business Excellence, 5(2), 6-12.

Neely, A., Gregory, M., \& Platts, K. (2005). Performance measurement system design: A literature review and research agenda. International Journal of Operations \& Production Management, 1228-1263.

Ngwenyama, O., \& Nielsen P. (2003). Competing values in software process improvement: An assumption analysis of CMM from an organizational culture perspective. IEEE Transactions on Engineering Management, 50(1), 100-112.

Ngwenyama, O., \& Norbjerg (2010). Software process improvement with weak management support: An analysis of the dynamics of intra-organizational alliances with IS change initiatives. European Journal of Information Systems, 19, 303-319.

Nielsen, P., \& Ngwenyama, O. (2002). Organizational influence process in software process improvement. Proceedings of the European Conference on Information Systems. Paper 107. Accessed on November 15, 2012. from http://aisel.aiset.org/ecis2002/107

Nudurupati, S., Bititci, U., Kumar, V., \& Chan, F. (2011). State of the art literature review on performance measurement. Computers \& Industrial Engineering, 60, 279-290.

Oakland, S., \& Oakland, J. (2001). Current people management activities in world-class organizations. Total Quality Management, 12(6), 773-788.

Palaniswamy, R., \& Frank T. (2000). Enhancing manufacturing performance with ERP systems. Information Systems Management, Summer, 43-55.

Paulk, M., Weber, C., Curtis, B., \& Chrissis, M. (1994). The capability maturity model: Guidelines for improving the software process. Reading: Addison-Wesley. 
Perrini, F., \& Tencati, A. (2006). Sustainability and stakeholder management: The need for new corporate performance evaluation and reporting system. Business Strategy and the Environment, 15, 296-308.

Pfeffer, J. (1981). Management as symbolic action: The creation and maintenance of organizational paradigms. In L. Cummings \& B. Staw (Eds.), Research in organizational behaviour (Vol 3) (pp. 1-52). Greenwich CT: JAI Press.

Pham, N., \& Swierczek, F. (2006). Facilitators of organizational learning in design. The Learning Organization, 13(2), 186-201.

Pourkomeylian, P. (2006). Software process improvement strategy. Proceedings of the European Conference on Information Systems. Paper 59. Accessed on November 15, 2012, from http://aisel.aisnet.org/ecis2006/59

Powell, T. (1995). Total quality management as competitive advantage: A review and empirical study. Strategic Management Journal, 16(1), 15-37.

Premkumar, G. (2000). Interorganizational systems and supply chain management: An information processing perspective. Information Systems Management, Summer, 56-69.

Rodgers, T. (1998). Enabling software process improvement through feedback mechanisms. Proceedings of the Americas Conference on Information Systems. Paper 424. Accessed on November 15, 2012, from http://aisel.aisnet.org/aimcis1998/424

Rust, R., Moorman, C., \& Dickson, P. (2002). Getting return on quality: Revenue, expansion, cost reduction, or both? Journal of Marketing, 66(4), 7-24.

Shredinck, H., Shutt, R., \& Weiss, M. (1992). Empowerment: Key to IS world-class quality. MIS Quarter$l y, 16(4), 491-505$.

Slaughter, S., \& Kirsch, L. (2006). The effectiveness of knowledge transfer portfolios in software process improvement: A field study. Information Systems Research, 17(3), 301-320.

Smeds, R., Haho, P., \& Alvesalo, J. (2003). Bottom-up or top-down? Evolutionary change management in NPD processes. International Journal of Technology Management, 26(8), 887-902.

Sousa, R., \& Voss, C. (2002). Quality management revisited: A reflective review and agenda for future research. Journal of Operations Management, 20(1), 91-109.

Staples, M., \& Niazi, M. (2008). Systematic review of organizational motivations for adopting CMM-based SPI. Information and Software Technology, 50, 605-620.

Strauss, A., \& Corbi, J. (1990). Basic qualitative research: Grounded theory procedures and techniques. London: Sage.

Strauss, A., \& Corbi, J. (1998). Basic qualitative research: Techniques and procedures for developing grounded theory. London: Sage.

Sturdivant, F., Ginter, J., \& Sawyer, A. (1985). Manager's conservatism and corporate performance. Strategic Management Journal, 4(2), 187-196.

Tanriverdi, H. (2005). Information technology relatedness, knowledge management capability, and performance of multibusiness firms. MIS Quarterly, 29(2), 311-334.

Turner, K., \& Makhija, M. (2006). The role of organizational control in managing knowledge. Academy of Management Review, 31(1), 197-217.

Tushman, M., \& Nadler, D. (1986). Organizing for innovation. California Management Review, 28(3), 7493.

Unterkalmsteiner, M., Gorschek, T., Islam, A., Cheng, C., Permadi, B., \& Robert, F. (2012). Evaluation and measurement of software process improvement- A systematic literature review. IEEE Transactions in Software Engineering, 8(2), 398-424. 
Visscher, K., \& Visscher-Voerman, J. (2010). Organizational design approaches in management consulting. Management Decision, 48(5), 713-731.

Way, S. (2002). Higher performance work systems and intermediate indicators of firm performance within the US small business firms. Journal of Business, 28(6), 765-785.

Whitty, S. J., \& Schultz, M (2007). Team project: A method of teaching project management?

Widen-Wulff, G., \& Ginman, M. (2004). Exploring knowledge sharing in organizations through the dimension of social capital. Journal of Information Science, 30(5), 448-458.

Wolfswinkel, J., Furtmueller, E., \& Wilderom, C. (2013). Using grounded theory as a method for rigorously reviewing literature. European Journal of Information Systems, 22, 45-55.

Zacharatos, A. Barling, J., \& Iverson, R. (2005). High-performance work systems and occupational safety. Journal of Applied Psychology, 90(1), 77-93.

Zmud, R. Boynton, A., \& Jacobs, G. (1986). The information economy: A new perspective for effective information systems management. Data Base, Fall, 17-23.

\section{Biographies}

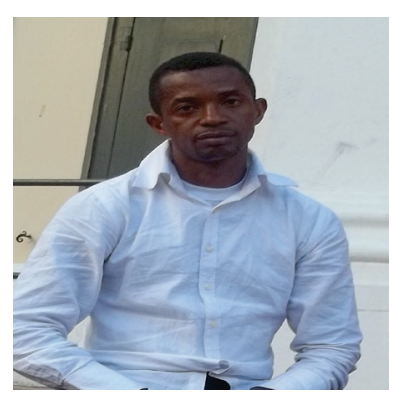

Samuel C. Avemaria Utulu is a PhD student at the Department of Information Systems, University of Cape Town, South Africa. He has worked as a systems librarian in two universities in Nigeria and currently works as the Senior Librarian in charge of the serials and government document librarian at the Redeemer's University, Nigeria where he was granted study leave till 2014. His research interests include open access publishing, webology, e-readiness assessment, library and information service modeling, and process analysis and improvement.

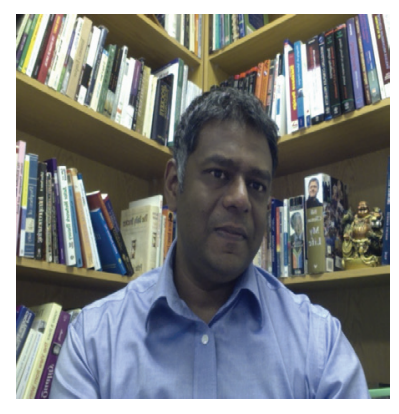

Kosheek Sewchurran. Currently, Associate Professor - Innovation Management and Information Systems at UCTs Graduate School of Business (GSB). Co-convenor of the MPhil in Inclusive Innovation studies at GSB. Leader of a research program aimed at reinventing the style of organizing for ICT work in collaboration with the Department of Trade and Industry (DTI) and Johannesburg Centre for Software Engineering (JCSE) and National team of PhD and MPhil students. Board Member of CAPACIT1000, a non-profit organization involved in sector development of the ICT industry and alleviating unemployment among graduates in South Africa. Member of the international editorial review board at International Journal of Managing Projects in Business. Member of the international editorial review board at International Journal of Information Technologies and Systems Approach (IJITSA). Member of the international editorial review board "TAPROOT Series", a cutting edge publication series of the DST/NRF SARCHI Chair in Development Education. NRF rated researcher ("Y") in Organizing Practices for High Innovation and Complex Contexts. Prior responsibilities include over a decade in large scale industrial expansion projects in the Aluminium Smelting, Casting and Rolling Business Sector spanning various professional roles from Program Management, Planning Specialist, Software Engineer, Enterprise Architect. And HOD - Department of Information Systems in Faculty of Commerce at UCT. 


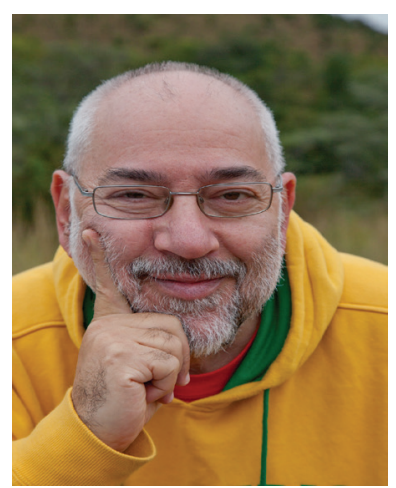

Barry Dwolatzky is Professor of Software Engineering in the School of Electrical \& Information Engineering at Wits University in Johannesburg. He is also Director of the University's "Joburg Centre for Software Engineering" (JCSE). After graduating from Wits with a $\mathrm{PhD}$ in Electrical Engineering in 1979 he spent 10 years in the UK working as a post-doctoral researcher at UMIST in Manchester, Imperial College in London and at the GEC-Marconi Research Centre in Chelmsford. He returned to Wits in 1989. Barry has published extensively on various software engineering topics. He was instrumental in the setting up of the JCSE in 2005. Over the past 10 years he has been a passionate advocate of the growth and success of the South African software development sector. 